\title{
VÝZKUM ARCHEOLOGIE SOUČASNOSTI V OBLASTI NOVOHRADSKÝCH HOR
}

KLíčoví SLOva: archeologie současnosti, konflikt, jižní Čechy, depopulace, archeologická transformace

KEYwords: archaeology of the contemporary past, conflict, South Bohemia, depopulation, archaeological transformation

\section{ÚvoD}

Příspěvek předkládá výběrový přehled výsledků archeologických aktivit na poli archeologie současnosti v oblasti Novohradských hor a Novohradského podhůří v Jihočeském kraji při státní hranici České republiky a Rakouska. Zkoumaný prostor je vymezen linií Šejby - Dlouhá Stropnice - Horní Stropnice - Rychnov u Nových Hradů - Benešov nad Černou - Ličov - Hradiště - Blansko - tok Malše před Kaplicí a dále proti toku Malše k Dolnímu Dvořišti až na státní hranici s Rakouskem a po státní hranici k hraniční obci Šejby a je možné jej označit jako podstatnou část Kaplicka, Benešovska a Novohradska. Jedná se o prostor 39 katastrálních území rozprostírajících se na ploše $282 \mathrm{~km}^{2}$.

Předmětem výzkumu byly vesnice a kulturní krajina zaniklé po roce 1945. Zkoumaný prostor byl $\mathrm{v}$ době po druhé světové válce postižen značným úbytkem obyvatelstva $\mathrm{v}$ důsledku vysídlení bývalých československých občanů německé národnosti, kteří v oblasti tvořili do roku 1945 většinovou populaci, a v důsledku následných hospodářských a společenských změn spojených zejména s kolektivizací, zánikem živností atp. 


\section{ArCheOlogie SOUČASNOSTI}

Diskuse nad pojetím archeologie nejnovějších období, které chronologicky následují archeologii postmedievální a nesouvisí s industrializací ani industriálními památkami, byla vedena $\mathrm{v}$ odborné literatuře již v sedmdesátých letech dvacátého století. V současné anglosaské archeologické literatuře, která je na práce archeologie nejnovějších období obzvláště bohatá, se lze setkat s termíny jako archeologie recentní minulosti nebo archeologie současné minulosti, přičemž oba termíny mají odlišný význam (Harrison, Schofield 2010; Holtorf, Piccini 2011). V české archeologické literatuře se setkáváme s termínem archeologie současnosti (Matoušek 2000: 4-17), který v sobě vhodně snoubí pojetí anglosaské s možnostmi českého jazyka a zažitých termínů v domácím prostředí. $\mathrm{V}$ poslední době se také poměrně často objevuje v českém prostředí označení „archeologie modernity“ (Neustupný 2013: 13-16; Vařeka 2013) pro tu část archeologické disciplíny, která zkoumá nedávnou minulost, resp. minulou současnost na podkladě archeologických pramenů tvořených moderními nikoliv však současnými artefakty a ekofakty, které jsou mrtvé a němé (Neustupný 2013: 13-16). Česká věda a kultura nabízí ke srovnání termíny z oboru dějin umění a termíny používané $\mathrm{v}$ historiografii. V dějinách umění se používá termín „moderní umění“, za které se považuje umění zhruba od 60. let 19. století do surrealismu, a pro následující období se používá termín „soudobé umění“. V architektuře se termín „moderna“ váže k období od konce 19. století do 1 . světové války. Za moderní dějiny se obvykle v historiografii považují dějiny od roku 1848, zatímco soudobé dějiny jsou od konce osmdesátých let dvacátého století chápány jako dějiny 20. století s pomyslným zlomem v roce 1945 (Vilímek 2014: 172). Archeologie studuje materiální kulturu, tedy to, co lidé po sobě zanechávají, z hlediska dlouhodobých procesů archeologické transformace. Tradiční archeologie pomocí svých metod, zejména klasifikace, třídění a tvorby logického řádu, vytváŕí z období neznámých a vzdálených, období známější a bližší, osvojuje si je. Archeologie současnosti zkoumá období, která (téměr̆) každý zná ze své vlastní zkušenosti a pomocí stejných metod transformuje známé na odtažité, které je možné podrobit analýze (Buchli, Lucas 2001: 9). Reverzní osvojení, vytváření ze známého neznámé umožňuje redukovat množství informací na informace relevantní. Zatímco tradiční archeologie získává informace z artefaktů, protože jiných zdrojů dat je nedostatečné množství, archeologie současnosti využivá artefaktů, aby artikulovala změt' stejně hlasitě znějících hlasů, kterými na nás promlouvá nedávná minulost (Buchli, Lucas 2001: 14). Principiálně stejný problém s pramennou základnou řeší i historiografie v soudobých dějinách:“ Zatímco historiografie starších údobí se snaží z mála údajů vyvodit co nejvíce důsledků, stojí před soudobými dějinami úkol opačný - záplavu údajů rozumně zjednodušit, či dokonce hledat to podstatné“" (Mayerová, Vašíček 2004: 27). 
Na rozdíl od tradiční archeologie není hlavním metodologickým nástrojem archeologie současnosti terénní výzkum odkryvem. Subdisciplinu lépe charakterizuje povrchový průzkum využívající celou řadu dnes rozvinutých nedestruktivních archeologických metod. Důležitou součástí metody archeologie současnosti je fotografie (Harrison, Schofield 2010: 51), at' již fotografie dokumentující minulost nebo fotografie postihující příznaky reliktu zkoumaného př̀edmětu.

\section{Pustnutí, zánik a Regenerace}

Pustnutí je proces, který může vést $\mathrm{k}$ zániku objektu, pokud nedojde $\mathrm{k}$ jeho regeneraci. Rychlé opuštění naráz vedoucí k trvalému zániku objektů nebo lokality bez budoucího znovuvyužití nebo znovuosídlení je spíše vzácné a souvisí nejčastěji s katastrofami (Tomka, Stevenson 1993: 192). Proces pustnutí je vymezen na jedné straně permanentním využitím objektu na druhé straně permanentní ztrátou využití, která vede $\mathrm{k}$ zániku. Mezi těmito extrémy může být využití pro občasné bydlení, využití jako sklad nářadí a náčiní, využití pro rekreaci, využití jakožto zdroje surovin na prodej nebo na stavbu nového objektu, či využití jako smetiště zejména poté, co dojde ke zř́ícení některých konstrukčních prvků nejčastěji střechy nebo stěn domu (srov. Rotschild a kol. 1993: 125). Osídlení je definováno jako kontinuální a nepřetržité užívání místa určitou skupinou (Schiffer 1996: 100). Opuštěné sídliště může být regenerováno stejnou skupinou lidí, která jej opustila, anebo jinou skupinou, což je častější jev (Schiffer 1996: 104). Ve sledovaném území Novohradských hor a vymezeném období lze ve velké miŕre sledovat opuštění a pustnutí, na nějž z určité části navazuje znovu využití a regenerace (obr. 1 a 2) a z další části zánik (obr. 3). Pouze v zanedbatelné míře lze sledovat kontinuitu a nepřetržité užívání místa stejnou skupinou at' již se jedná o autochtonní Čechy nebo neodsunuté Němce.

Jako základní jednotka výzkumu zaniklých vesnic a kulturní krajiny Novohradských hor byla zvolena komponenta jakožto analytická jednotka, s jejiž pomocí lze popsat sídelní areály. Za komponentu je považován funkčně rozdílný celek, tj. takový celek, který se svojí funkcí odlišuje od celku jiného), jako např̀. usedlost, dům, výrobní objekt, těžební areál, cesta, pole, pastvina, sad, rybník, regulovaný tok, apod. Komponenty, které spolu prostorově souvisejí a v minulosti byly produktem určité komunity, vytvářejí sídelní areál (tj. osady, vesnice a městyse včetně příslušného zemědělského a nezemědělského zázemí). U některých komponent není možné na základě archeologických ani historických pramenů určit jednoznačnou prríslušnost do některého sídelního areálu a zůstávají samostatné (osamocené zemědělské usedlosti, mlýny, hájovny, některé výrobní objekty, rybníky). Část z těchto samostatných komponent měly nadkomunitní význam (mlýny, hájovny, výrobní objekty a rybníky) (srov. Neustupný 2010: 


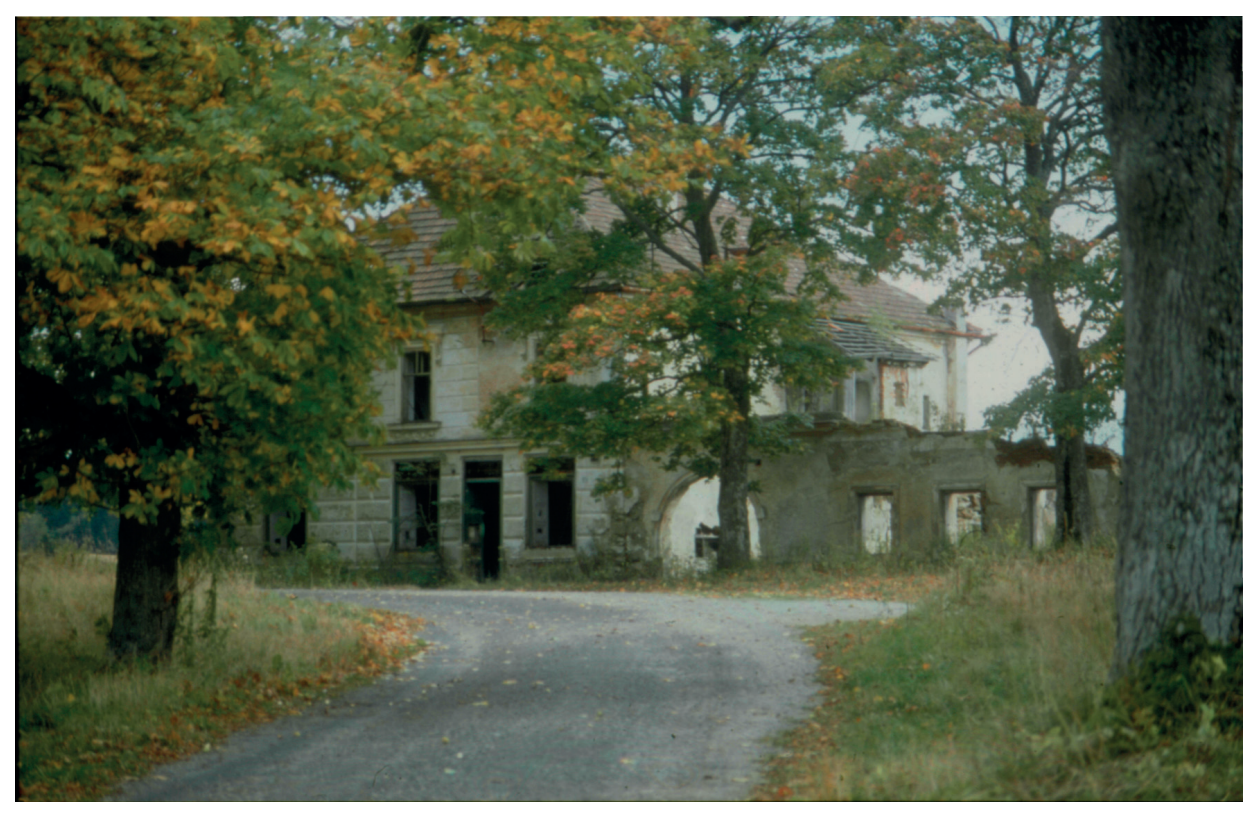

Obr. 1. Pohoří na Šumavě (Puchers), k. ú. Pohoří na Šumavě: Opuštěné domy čp. 14 a 86 na návsi zaniklé vesnice po otevření zakázaného pásma. Před rokem 1945 byl v domě čp. 14 konzum a četnická stanice a v domě čp. 86 poštovní úřad (foto M. Bureš, podzim 1993).

148-149). K nadkomunitním komponentám náleží též suchozemské cesty mezi sídelními areály a dálkové cesty jakož i vodní cesty včetně novohradského dřevoplavebního systému (Bureš, Pařez 2006: 679-686).

Pro odlišení jednotlivých př́ípadů byly definovány stupně transformace, podle toho, $\mathrm{v}$ jaké míře areály a komponenty prošly, respektive neprošly zánikovou transformací (Neustupný 2007: 51). Transformační škála odráží vztah pustnutí, zániku a regenerace čili míru přechodu mezi živou a mrtvou kulturou, respektive míru přechodu mezi systémovým a archeologickým kontextem (Schiffer 1996). Transformační škála je u areálů čtyřstupňová u komponent pouze dvoustupňová. Areály jsou členěny na plně funkční, částečně funkční, nefunkční a zaniklé; komponenty na funkční a zaniklé. Plně funkční areál slouží i v současnosti jako komunitní areál s př́slušnou infrastrukturou adekvátní současnému komunitnímu areálu. Charakteristickou vlastností žijícího areálu je, že neproběhla zániková transformace areálu jako celku. Částečně funkční areál představuje komunitní areál sice $\mathrm{z}$ podstatné části zaniklý, ale $\mathrm{v}$ jeho rámci se zachovaly areály aktivit, které slouží svému původnímu účelu (např. několik zemědělských usedlostí, zemědělský provoz, trvale obývané budovy apod.). Přesto, že významná část komponent prošla zánikovou transformací, areál ne- 
prošel zánikovou transformací jako celek. Nefunkční sídelní areál je charakterizován zánikem převažující většiny komponent. Zachované komponenty neslouží svému původnímu účelu, jako celek netvoří z důvodu absence komunity komunitní areál. $Z$ větší části zaniklý sídelní areál nedisponuje infrastrukturou žijícího sídla. Jako typický příklad lze uvést vesnici nebo osadu, v jejímž obvodu zanikla většina zemědělských usedlostí a ty které nezanikly, neslouží jako zemědělské usedlosti, ale neslouží ani k stálému obývání. Bývalé usedlosti jsou prázdné, nevyužívané, nebo slouží jako rekreační objekty. U částečně funkčních a nefunkčních areálů není rozhodující poměr mezi funkčními a zaniklými komponentami, ale skutečnost, zda se $\mathrm{v} v$ areálu zachovaly aktivity sloužící původnímu účelu nebo nikoliv. V zaniklém sídelním areálu všechny komponenty prošly zánikovou transformací, avšak mohly projít různými druhy zejména kulturních postdepozičních transformací. Nelze tedy vyloučit př́itomnost fyzicky stojících objektů, nebo jejich částí a pozůstatků, tyto objekty jsou však prázdné, nevyužívané a neslouží ani jako rekreační objekty. U jednotli-

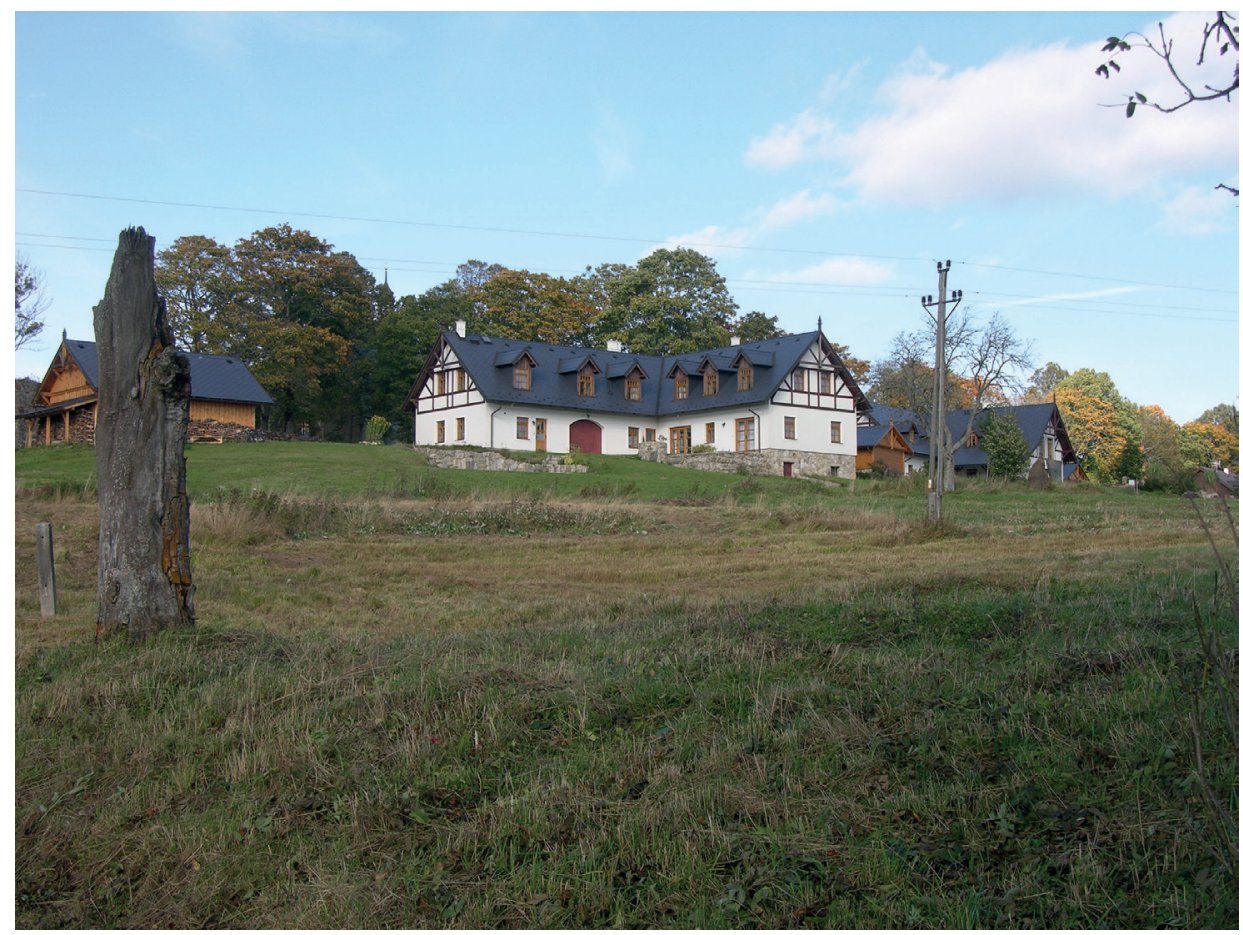

Obr. 2. Pohoří na Šumavě (Puchers), k. ú. Pohoří na Šumavě: nové rekreační sídlo vzniklé v prvním desetiletí 21 . století na troskách zaniklých domů čp. 14 a 86

(foto M. Bureš, září 2010). 


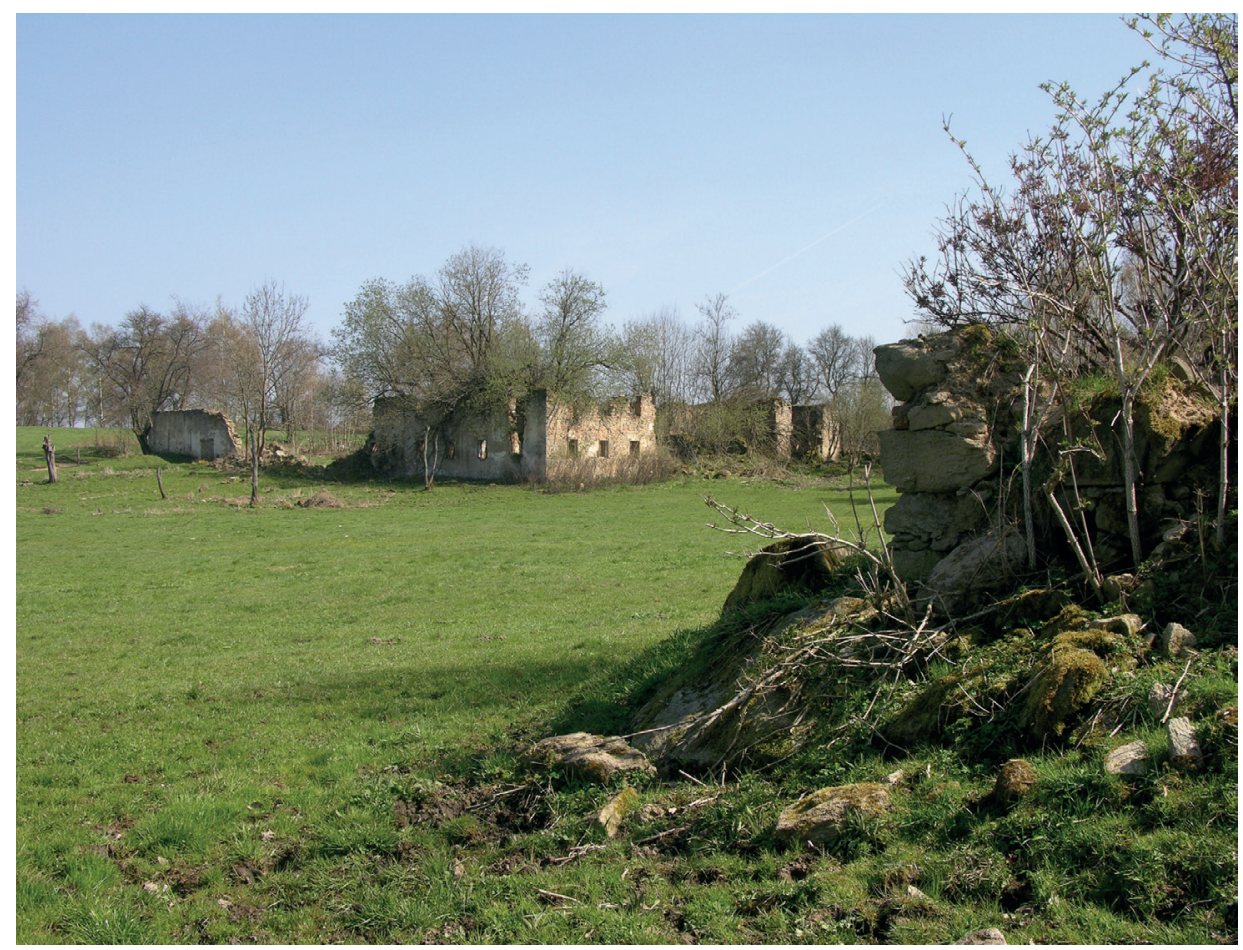

Obr. 3. Drochov (Drochersdorf), k. ú. Všeměřice: zaniklá usedlost (foto M. Bureš, duben 2011).

vých komponent jsme rozlišovali pouze, zda je komponenta funkční nebo zaniklá. Funkční komponenta slouží svému původnímu účelu v rámci komunitního nebo nadkomunitního areálu nebo svému účelu neslouží, ale neprošla zánikovou transformací (např. usedlost využívaná jako rekreační objekt). Nefunkční areál tak obsahuje zaniklé i funkční komponenty; zaniklý areál obsahuje pouze zaniklé komponenty. Mezi zaniklé komponenty řadíme i takové komponenty, které prošly zánikovou transformací, ale stavební relikty byly využity pro novou výstavbu zejména rekreačních, v některých př́padech i hospodářských objektů. Pro zařazení mezi zaniklé komponenty je rozhodující, zda nová stavba přistupuje $\mathrm{k}$ reliktu jako $\mathrm{k}$ př́rodnímu útvaru využitelnému pro novostavbu (např. pozůstatek obvodové zdi usedlosti využit jako součást novostavby). Naopak takové komponenty, z kterých zůstala jen stavební torza, avšak se zachovanými napřr. někdejšími obytnými prostory s okenními otvory atd. a byly nově využity jako obytné prostory s okny v původních otvorech atp., práce řadí mezi funkční. Takových př́ípadů regenerace je však velmi málo, anebo tento stav nelze okulární observací identifikovat. Transformační škála byla aplikována na 
39 katastrálních území vymezeného území. Z celkového počtu 95 areálů, bylo určeno 41 areálů jako plně funkčních, 9 částečně funkčních, 11 nefunkčních a 34 zaniklých (Bureš 2015: 21-22). Pro další potřeby výzkumu byla na základě předvýzkumu nefunkčních a zaniklých sídelních areálů vytvořena typologie způsobu zániku domů a usedlostí. Definována byla jednorázová úplná destrukce (obr. 4-5), jednorázová částečná destrukce (obr. 6-7) a samovolná postupná destrukce (obr. 3). Typologie zániku také vyjadřuje pravděpodobný způsob demolice a míru recyklace materiálu (srov. Schiffer 1996: 106-107; Klír 2008: 183-184). V závislosti na záměrném nakládání se zbytky v průběhu zániku (srov. Neustupný 2007: 53-54) byly dále odlišeny formy jednorázové úplné destrukce, a to úplná destrukce provedená beze zbytku, se zbytky ponechanými v místě volně rozptýlenými (obr. 8-9), se zbytky ponechanými v místě shrnutými do náspu (obr. 10-11) a konečně se zbytky ponechanými v místě vyrovnanými do mohyly (obr. 12) (Bureš 2015: 22-23).

\section{ZÁNIK ZEMĚDĚLSKÉHO OSÍDLENÍ V PODHŮŘíi NOVOHRADSKÝCH HOR}

Historické procesy spojené s depopulací oblasti, respektive jejich odraz ve hmotných pramenech lze zkoumat i archeologicky, prričemž pramennou základnu zde tvoří nepřeberné množství zaniklých vesnic. Zánik zemědělského osídlení $\mathrm{v}$ poměrně hlubokém vnitrozemí $\mathrm{v}$ důsledku úspěšné kolektivizace lze demonstrovat na př́íkladu vesnice Velíško.

První písemná zpráva o vesnici Velíško (něm. Wölschko) pochází z roku 1361 (Řezníčková 2006: 314). Vznik vesnice, která leží v podhưří Novohradských hor v nadmořské výšce $646 \mathrm{~m}$ n. m., souvisí se zemědělskou kolonizací oblasti. Indikační skica Stabilního katastru zachycuje Velíško jako krátkou lesní lánovou ves $\mathrm{s}$ dvěma řadami domů podél potoka s paralelní cestou v ose vesnice. Na usedlosti navazují záhumenice. $Z$ hlavní cesty v ose vesnice vycházejí polní cesty podél jednotlivých polních parcel. Toto schéma si Velíško udržuje až do počátku 50. let dvacátého století (obr. 18), kdy se začíná razantně měnit.

Zánik vesnice Velíško byl dlouhodobý proces, který započal po roce 1945 a skončil až v sedmdesátých letech dvacátého století. Trval tedy více jak 25 let. Archeologický obraz vesnice do roku 1952 vykazuje zřetelnou stabilitu. Počet usedlostí se redukuje jen velmi nepatrně, zemědělská půda je obdělávána v hranicích původních parcel (obr. 13). Ke změně dochází mezi lety 1952 až 1958. V tomto období sice dochází k zavedení elektrického proudu, avšak jak vyplývá z detailního studia leteckých snímků z roku 1958, elektřina je rozvedena už po zániku některých usedlostí. $\mathrm{V}$ tomto období je též odkloněna páteřní komunikace z centra vesnice na její obvod a význam této obvodové komunikace jako hlavní v následujících období dále stoupá. V roce 1958 je dle svědectví letec- 


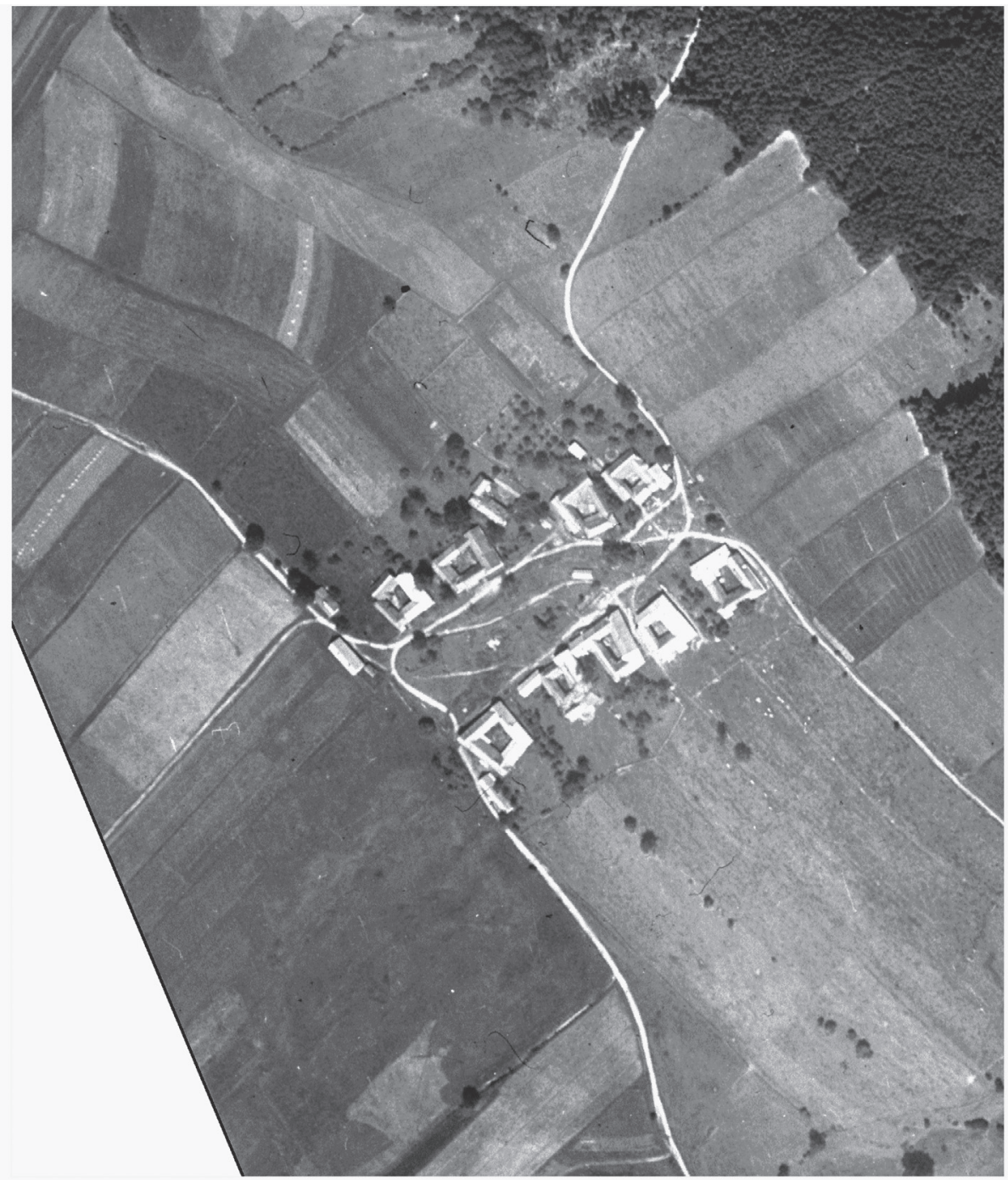

Obr. 4. Polžov (Pilsenschlag), k. ú. Lužnice: letecký snímek vesnice z roku 1947 (Vojenský geografický a hydrometeorologický úřad v Dobrušce, letecký měřičský snímek 2439/1947). 


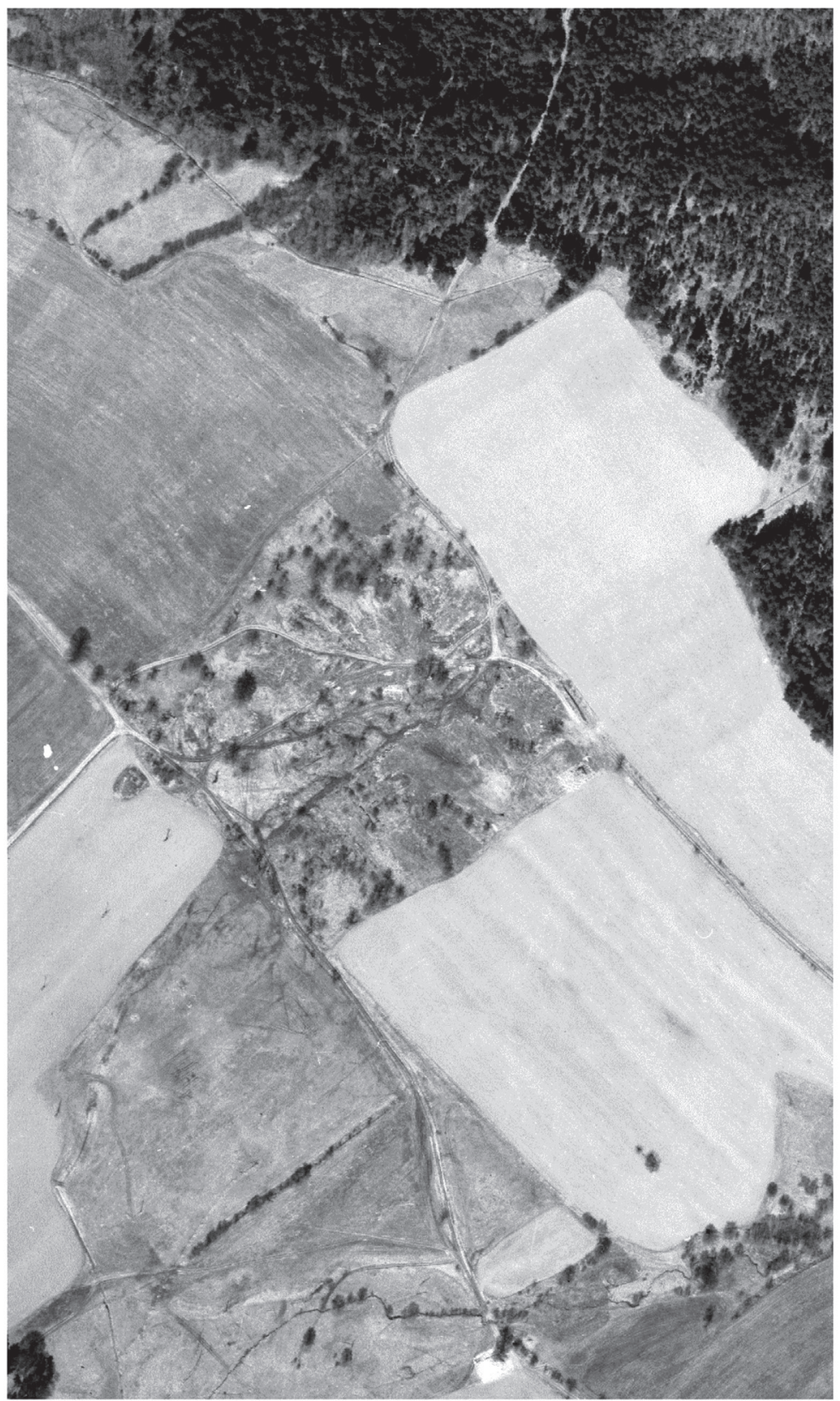

Obr. 5. Polžov (Pilsenschlag), k. ú. Lužnice: letecký snímek úplně destruované vesnice z roku 1967 (VGHMÚř, letecký měřičský snímek 02076/1967). 


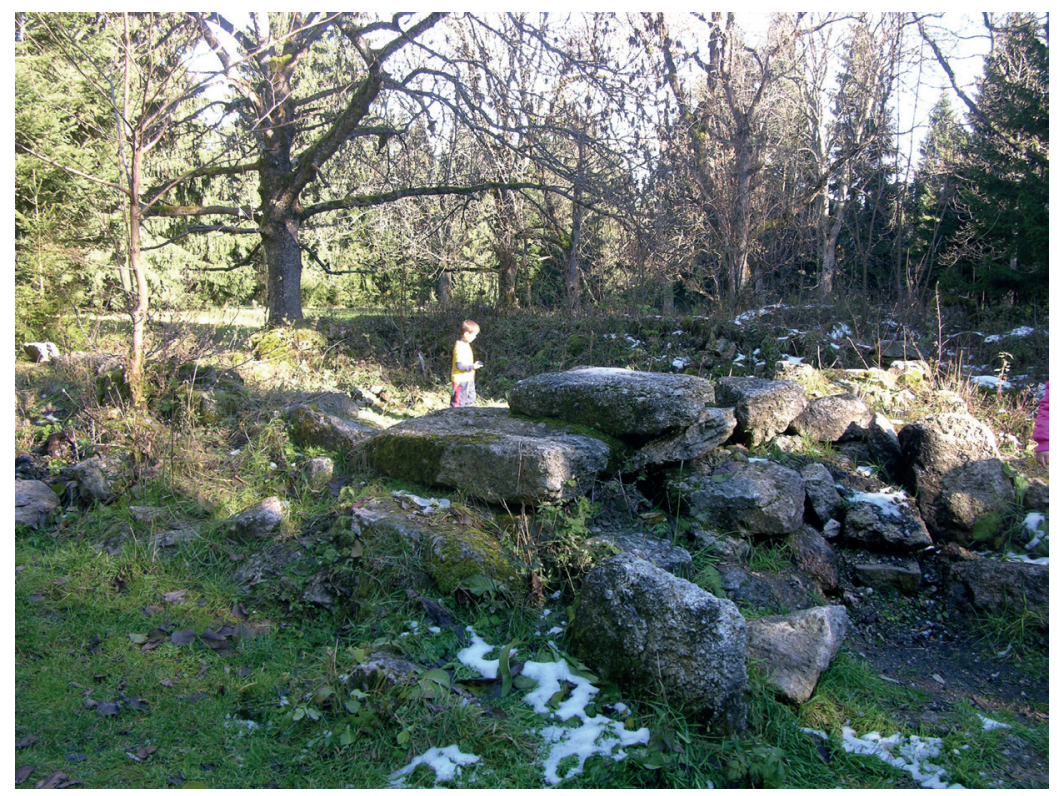

Obr. 6. Schwartzviertel, k. ú. Pohoří na Šumavě: příklad usedlosti zaniklé jednorázovou částečnou destrukcí (foto M. Bureš, ř́íjen 2010).

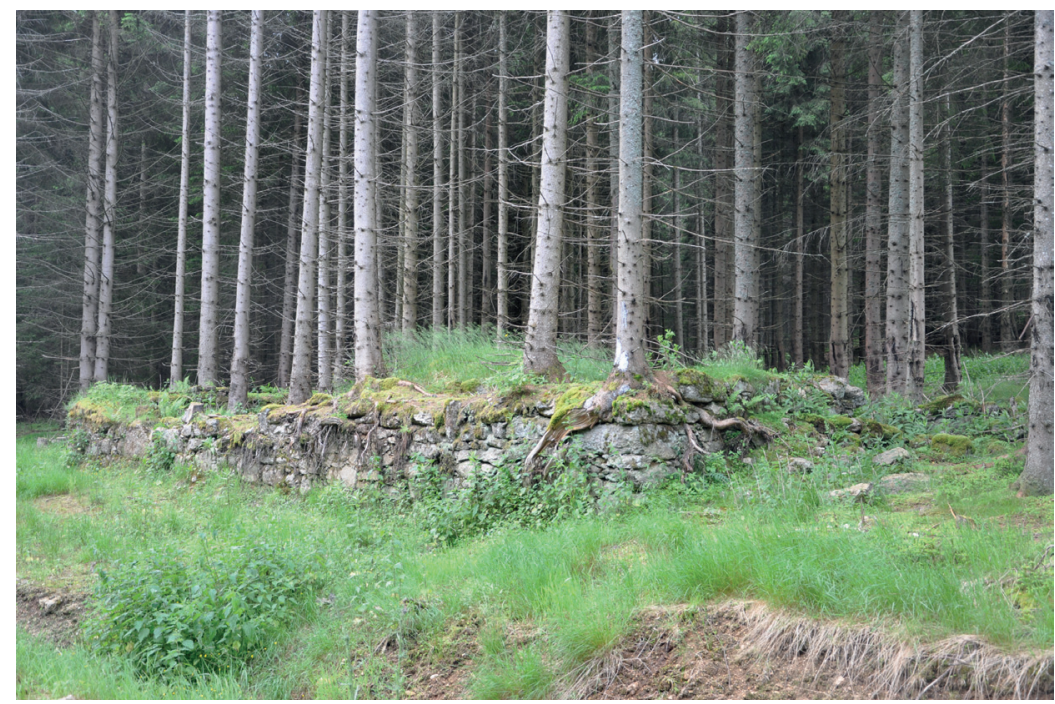

Obr. 7. Staré Šance (Schanz), k. ú. Pohoří na Šumavě: domy podél dálkové cesty do Freistadtu vesměs zanikly jednorázovou částečnou destrukcí a relikty se dodnes zachovaly do výše nejméně metr nad současný povrch (foto M. Bureš, květen 2010). 


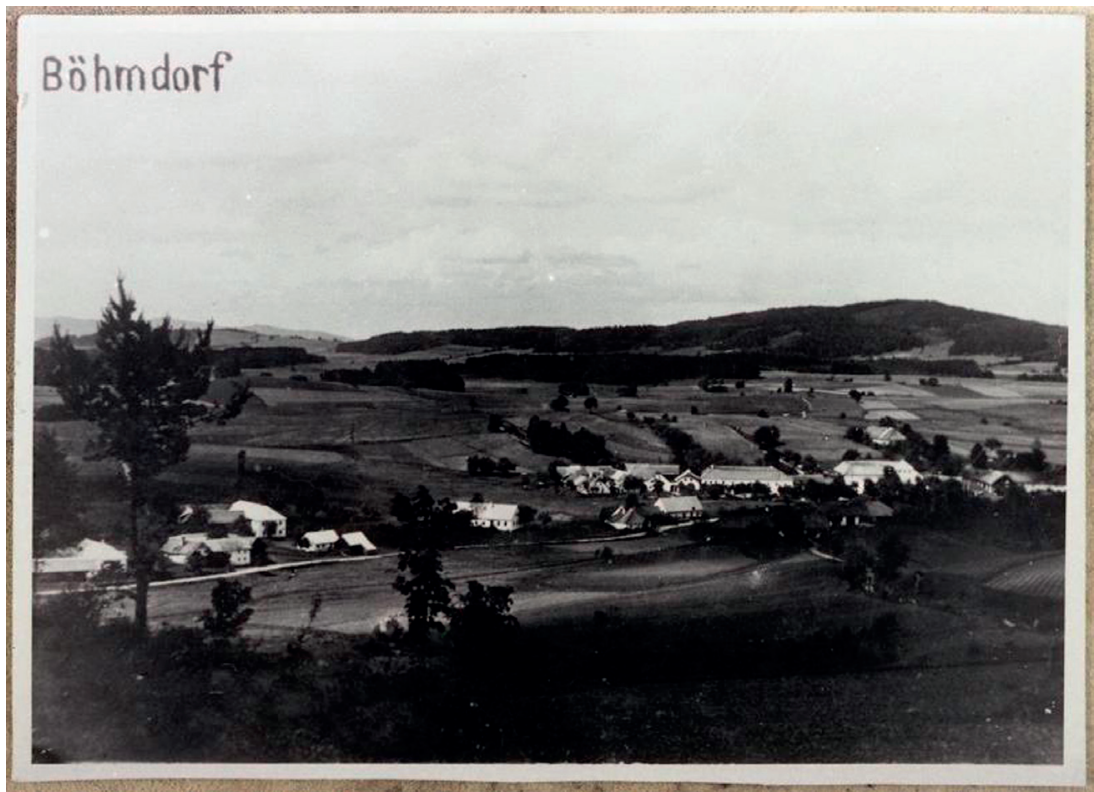

Obr. 8. Mikulov (Böhmdorf), k. ú. Mikulov: pohled na část A zaniklé vsi - stav před rokem 1945 (http://www.bwb-ooe.at/, navštíveno 28.05.2016).

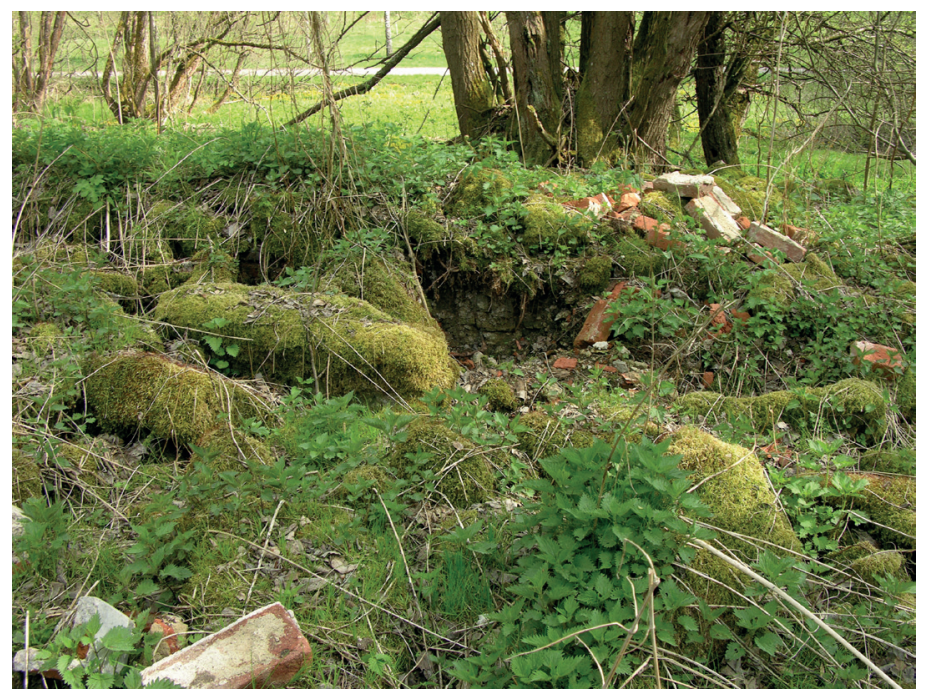

Obr. 9. Mikulov (Böhmdorf), k. ú. Mikulov: destruovaná usedlost $\mathrm{v}$ části A zaniklé vesnice se zbytky ponechanými v místě - stav v roce 2011 (foto M. Bureš, duben 2011). 


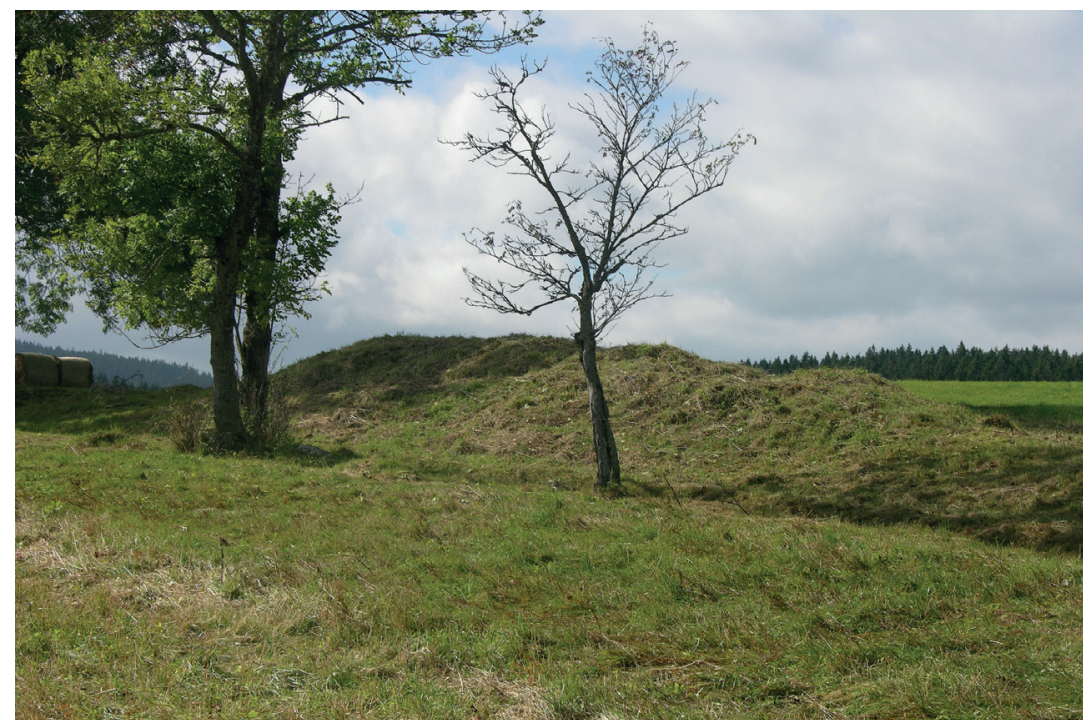

Obr. 10. Nové Šance (Neu Schanz), k. ú. Pohoří na Šumavě: úplná destrukce usedlosti se zbytky ponechanými v místě shrnutými do náspu reprezentuje bývalé čp. 102 , z něhož byl dne 27 . března 1947 vysídlen osmdesátiletý tkadlec Johann Wichro se svou sestrou, snachou a dvěma vnoučaty (foto M. Bureš, květen 2009).

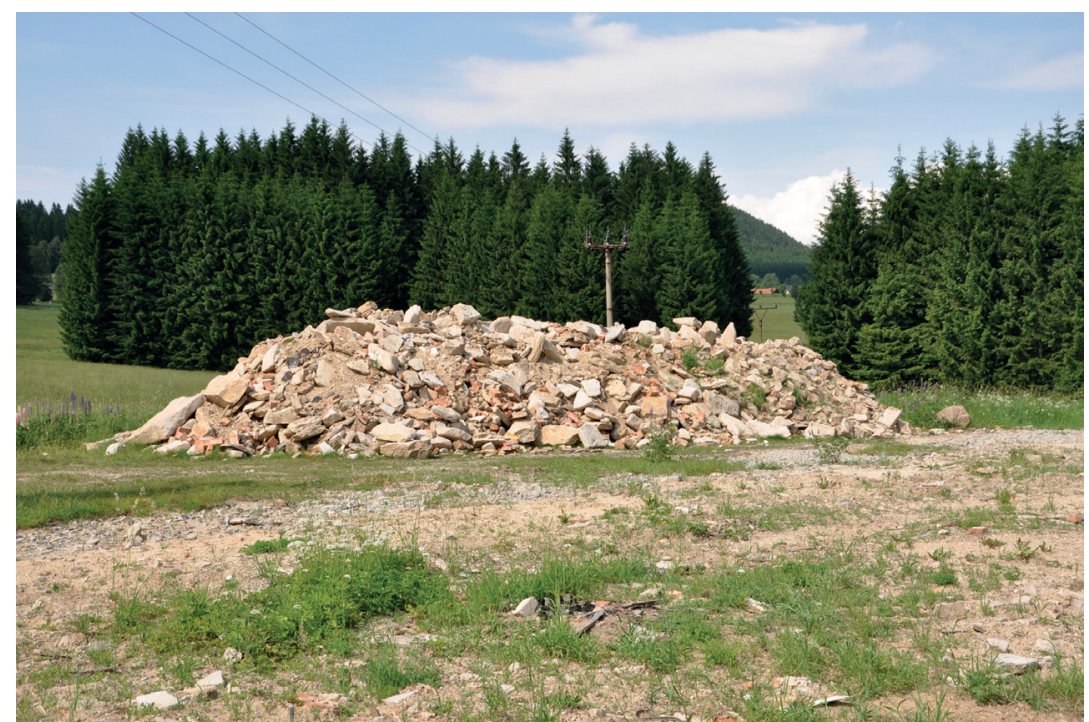

Obr. 11. Mlýnský Vrch (Mühlberg), k. ú. Staré Hutě: původně mlýn, později rekreační středisko OV KSČ. Úplná destrukce se zbytky ponechanými v místě shrnutými do náspu proběhla v tomto př́ípadě až v roce 2013 (foto M. Bureš, červen 2013). 


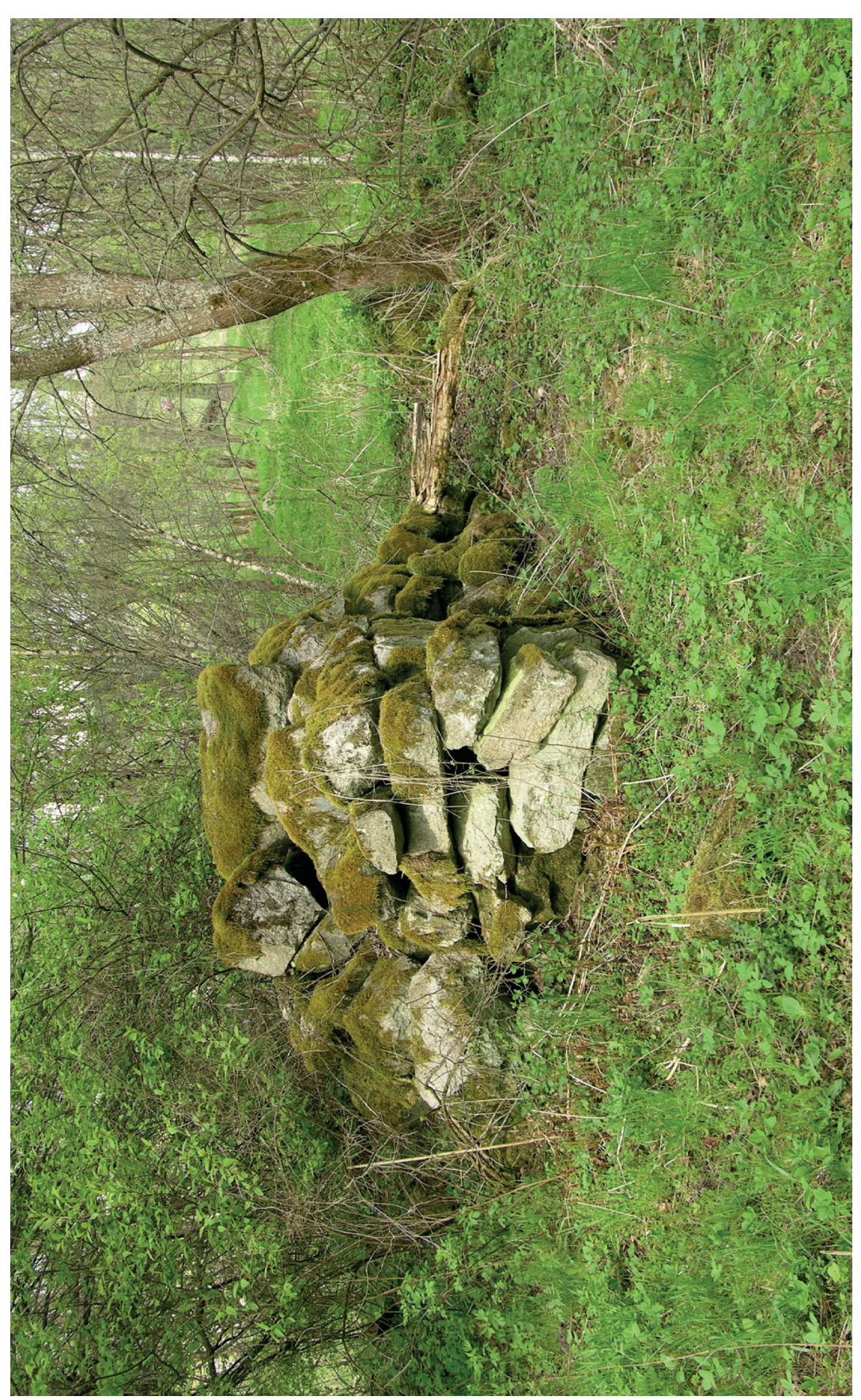

政 


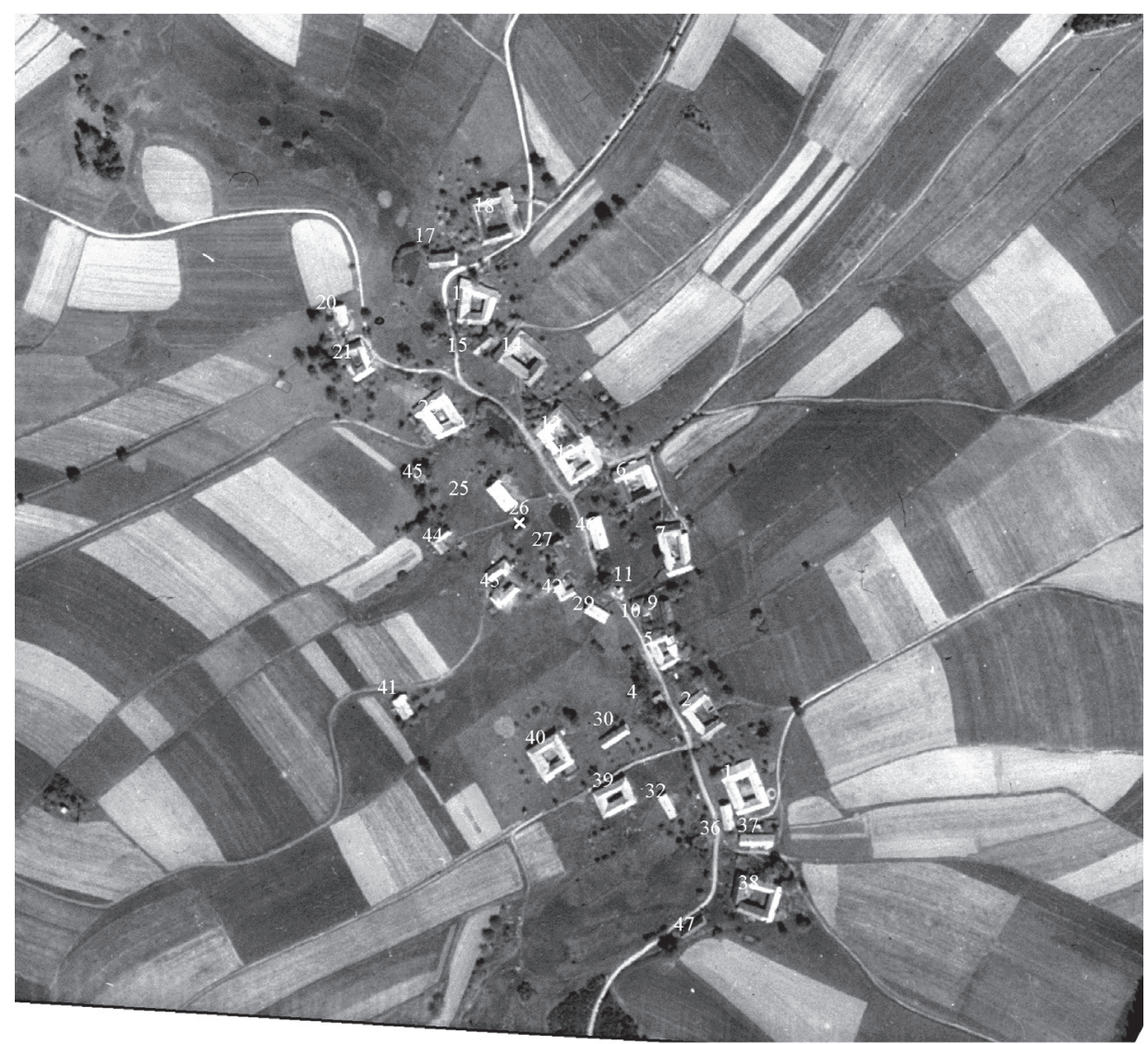

Obr. 13. Velíško (Wölschko), k. ú. Meziřićí, letecký snímek vesnice z roku 1949 (VGHMÚř, letecký měřičský snímek 06540/1949).

kého snímku zemědělská půda sice obdělávána ještě zčásti v mezích původních parcel, část parcel je však již sjednocena (obr. 14). Důležité je však zejména, že obdělávaná zemědělská půda se vesnici začíná vyhýbat a polní parcely již nenavazují na usedlosti. Tento jev souvisí i s přesunem hlavní cesty z centra vesnice na její obvod. Usedlosti nejsou spojeny s polními parcelami, obdělávání půdy není zřetelně realizováno $\mathrm{z}$ usedlostí vesnice, ale pracovní síla je s pracovními prostředky přiváděna $\mathrm{z}$ vnějšku areálu. Komunikace nespojují usedlosti, ale vyhýbají se jim. Celkový počet usedlostí mezi léty 1952 a 1958 se redukuje z 32 na 20. Zaniká většina chalup a zmenšuje se velikost dvorů. Mezi léty 1958 až 1967 pokračují nastoupené trendy. Vesnice je v podstatě odříznuta od zemědělské půdy, ke které původně náležela. Hlavní komunikace umožňuje př́stup $\mathrm{z}$ vnějšku $\mathrm{k}$ zemědělské půdě, ale usedlosti uvnitř vesnice s ní postrádají spo- 


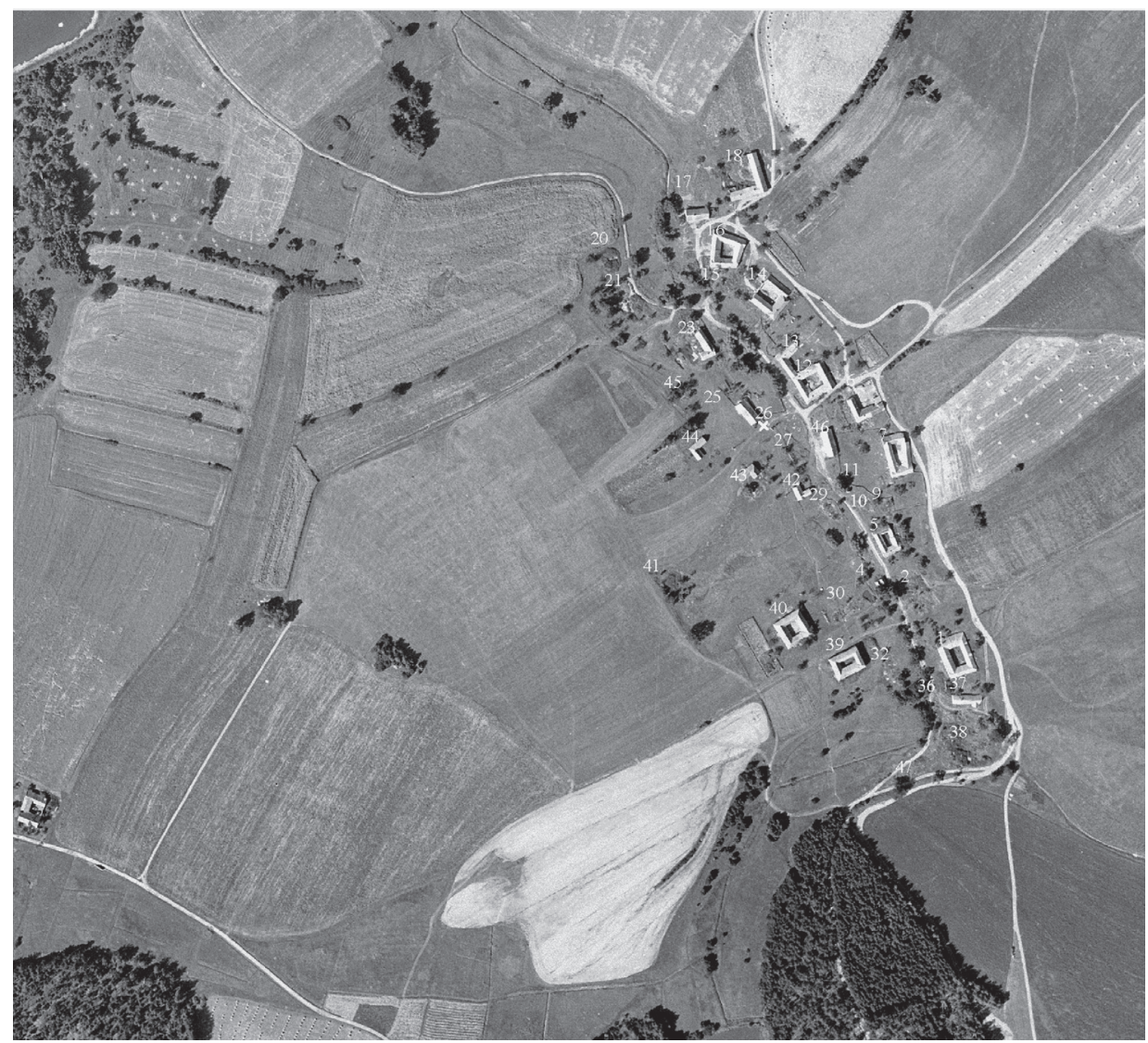

Obr. 14. Velíško (Wölschko), k. ú. Meziříčí, letecký snímek vesnice z roku 1958 (VGHMÚř, letecký měřičský snímek 14618/1958).

jení. Původní polní a luční parcely jsou sjednoceny, pole po staletí obdělávaná po vrstevnici jsou nově oraná po spádnici. Zanikají všechny polní cesty. V roce 1967 letecké snímky registrují pouze 12 usedlostí (obr. 15). Zánik vesnice je dokonán mezi léty 1967 a 1983. Na leteckém snímku z roku 1983 již nejsou patrné žádné usedlostí (obr. 16). Prostor vesnice je obepnut zemědělskou půdou a pracovní síly a mechanizace jsou prriváděny $\mathrm{k}$ polím po cestách, které jsou vedeny $\mathrm{z}$ větší části po obvodu někdejší vsi. Prostor aplanovaných usedlostí na jihozápadním okraji někdejší vesnice však není využíván jako orná půda a slouží jako louky, ale daleko pravděpodobněji leží ladem, a postupně zarůstá náletem stejně jako centrální části někdejší vesnice. Data získaná nedestruktivním archeologickým výzkumem lze srovnat s informacemi, které pro ves Velíško poskytuje historiografie. V roce 1930 měla obec 36 domů, které obývalo 132 


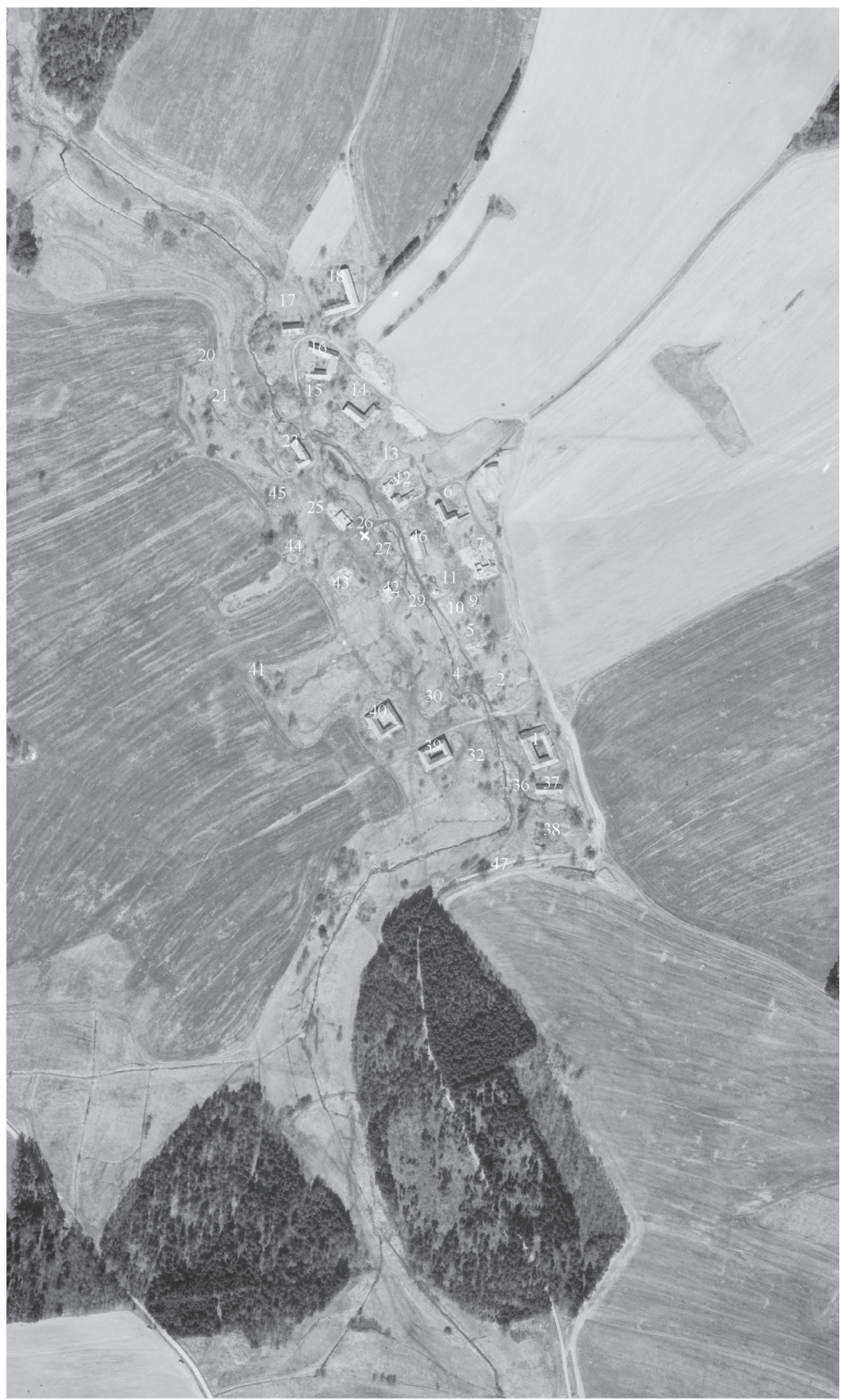

Obr. 15. Velíško (Wölschko), k. ú. Meziříčí, letecký snímek vesnice z roku 1967 (VGHMÚř, letecký měřičský snímek 02059/1967). 


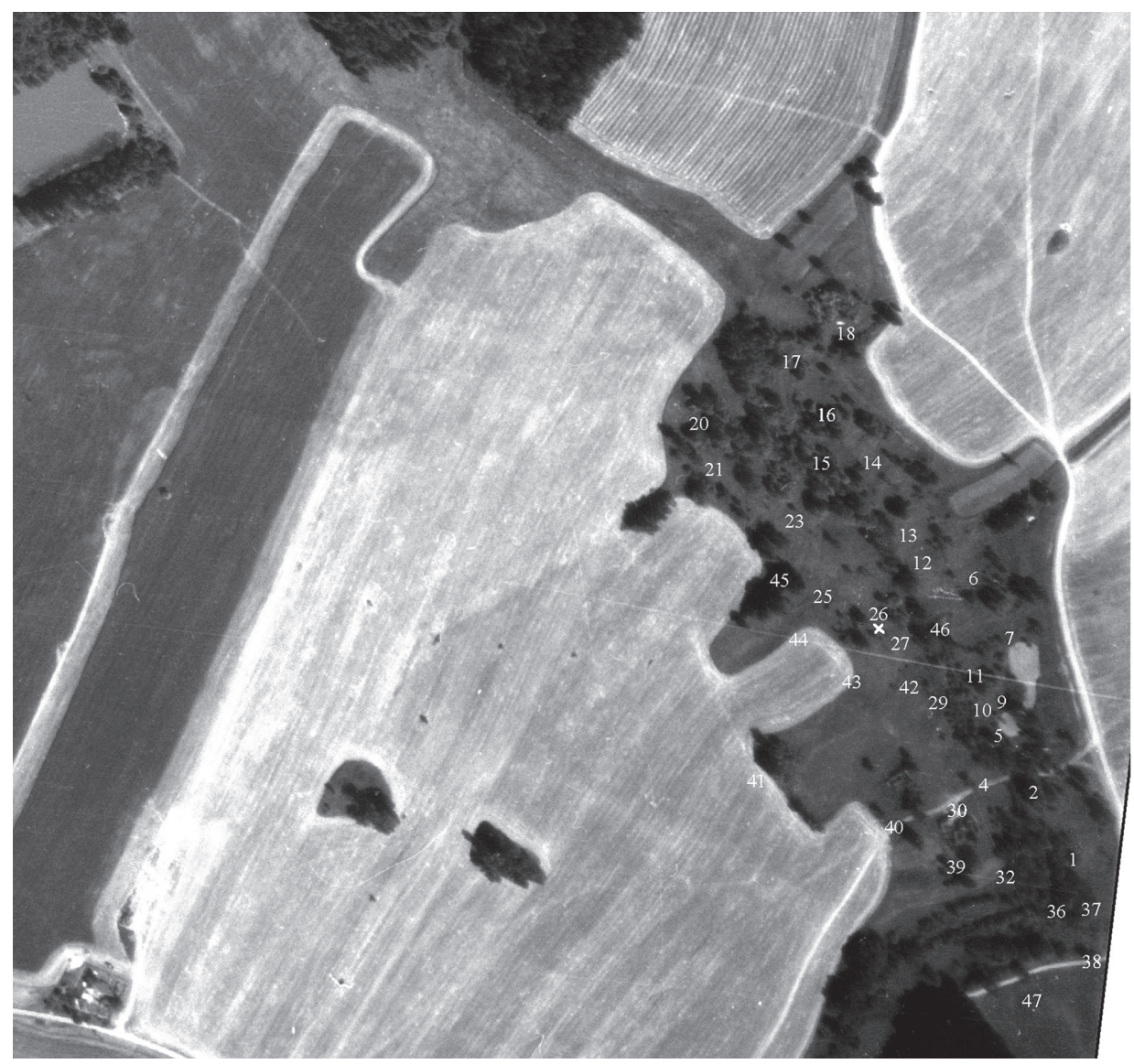

Obr. 16. Velíško (Wölschko), k. ú. Meziříćí, letecký snímek vesnice z roku 1983 (VGHMÚř, letecký měřičský snímek 12168/1983).

obyvatel německé národnosti (Statistický lexikon... 1934); v roce 1950 obývalo 15 domů 77 Čechů (Statistický lexikon... 1955). Pro rok 1961 není počet domů znám, protože již došlo $\mathrm{k}$ administrativnímu připojení vsi k sousední obci Meziříčí u Malont a počty domů uvedl statistický lexikon pouze souhrnně, ale ve Velíšku již žilo pouze 26 stálých obyvatel (Statistický lexikon... 1966). V roce 1970 se uvádí „0“ domů a „0“ obyvatel (Statistický lexikon... 1976), aby v roce 1973 vesnice oficiálně zanikla (Zeměpisný lexikon ČR... 1991). Na základě písemných pramenů nejen statistického charakteru by bylo možno Velíško interpretovat jako vesnici po roce 1945 nedosídlenou, která nějaký čas setrvávala v agónii, aby na počátku sedmdesátých let zcela zanikla. Archeologie vypovídá o víceméně úspěšně dosídlené vesnici, jejíž struktura byla zásadním způsobem 
narušena změnou systému využívání zemědělské půdy spojenou s kolektivizací, která vedla k odř́znutí usedlostí od půdy a jejímž důsledkem bylo obdělávání zemědělské půdy ze sousedního Meziříčí, kde sídlil provoz zemědělského družstva, respektive státních statků. Usedlosti se patrně postupně stávaly pouze ubikacemi vzdálenými od práce i infrastruktury. Takové ubikace sice vydržely nějaký čas též $\mathrm{v}$ důsledku zavedení elektřiny, ale bez vazby na půdu, bez komunikací a infrastruktury, s delší docházkovou vzdáleností do práce i $\mathrm{k}$ veřejné hromadné dopravě vesnice zaniká.

\section{ZÁNIK OSÍDLENí V BEZPROSTŘEDNí BLÍZKOSTI HRANIC S RAKOUSKEM}

Většina sídel při hranicích $\mathrm{s}$ Rakouskem byla původně nezemědělského charakteru (sklářství, dřevařství), $\mathrm{v}$ příhodných podmínkách existovaly těsně u hranic i vyloženě zemědělské osady a vesnice, které spiše, než na zemědělské osídlení v českém vnitrozemí navazovaly na stejný druh osídlení na rakouské straně hranic. Př́kladem zaniklé zemědělské osady v těsné blízkosti hranic může být Lhota u Cetvin (něm. Neustift).

Blízkost hranice s Rakouskem (cca $200 \mathrm{~m}$ ), která druhdy byla pro osadu spíše výhodou vyplývající z napojení na přístupnější a intenzivnější zemědělské osídlení rakouské strany, znamenala po roce 1945 rychlý zánik. I přes malý soubor leteckých snímků, kdy jsou $\mathrm{k}$ dispozici pravděpodobně právě z důvodů bezprostřední blízkosti hranic pouze snímky z let 1949 a 1952, se nám dostává pramenné základny pro zkoumání. Na snímku z roku 1949 je patrné, zejména ve srovnání s přilehlým územím Rakouska, že vesnice je v době snímkování opuštěná, pravděpodobně vůbec nedosídlená, přestože usedlosti ještě nezanikly; polní parcely areálu jsou již neobdělávané. Letecký snímek z roku 1952 zachycuje Lhotu již jednoznačně zaniklou (obr. 17). Povrchový průzkum realizovaný v dubnu 2011 ukázal, že po roce 1952 byly usedlosti zdemolovány a většinou po spádnici shrnuty do náspů či valů. Zaměřením náspů se ukázalo, že přerušení náspu ve dvou př́ípadech ze tří koresponduje $\mathrm{s}$ mezerou v zástavbě. Severně od náspů, tedy vně vesnice, bylo území usedlostí rekultivováno. Vzhledem k malé četnosti leteckého snímkování oblastí těsně se přimykajících $\mathrm{k}$ hranici nelze určit, zda $\mathrm{k}$ částečné rekultivaci komponent 1-9 došlo v rámci demolic anebo až nějaký čas po nich. Analogicky podle jiných lokalit s podobným osudem je pravděpodobnější, že k rekultivaci území usedlostí došlo až později, nejpravděpodobněji v souvislosti s meliorací, resp. s regulací, toku Malše (obr. 19). To ovšem platí i o ostatních rekultivovaných území někdejších domů vesnice Lhota. Patrně z důvodů větší roztroušenosti staveb, byly některé domy (např. 10-14 na obr. 17) jenom strženy a zbytky byly ponechány v místě, což v důsledku znamenalo, že některé relikty, zejména půdorysy domů, se dobře zachovaly. Dobře zachované 


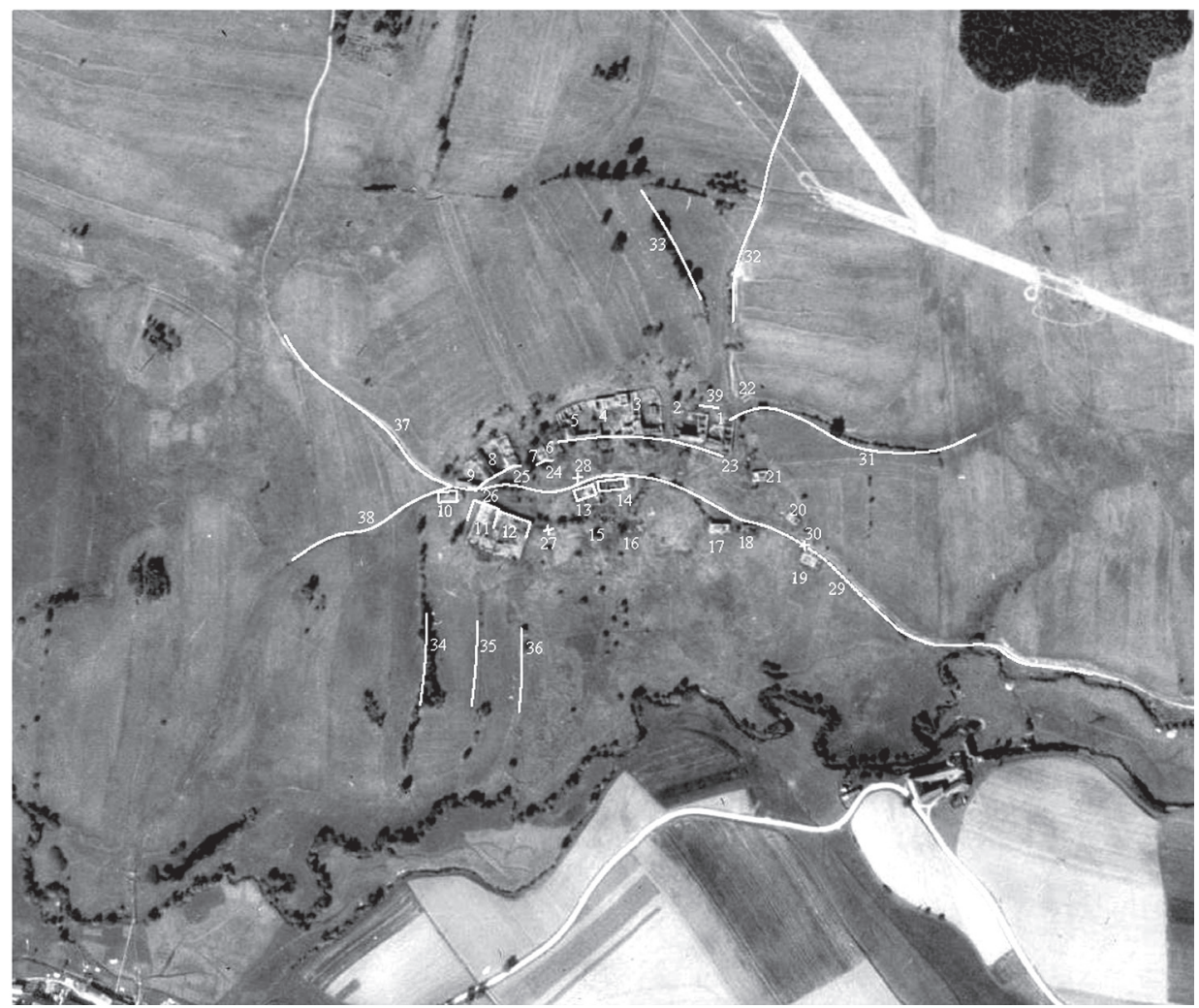

Obr. 17. Lhota (Neustift), k. ú. Cetviny, letecký snímek z roku 1952

(http://www.kontaminace.cenia.cz/, navštíveno 11.08.2017).

jsou relikty domu 13 (obr. 17), kde kromě vcelku běžně dochovaného zčásti propadlého sklepa se dochovala $\mathrm{v}$ někdejším interiéru domu $\mathrm{v}$ podstatě celá pohřbená kachlová kamna. $V$ bezprostřední blízkosti domu 13 a cesty probíhající návsí se dochoval snos stavebního kamení (obr. 12), který dokládá těžbu stavebního materiálu při demolici staveb. Do stavebně upraveného, leč v té době již nefunkčního úseku cesty ze Lhoty k Malši, tj. ke státní hranici, byla v poválečném období zamaskována pozorovatelna pohraniční stráže (obr. 18), která byla otevřena směrem na Leopoldschlag Markt. V tomto směru byla rovněž obzvláště důkladně regulována Malše, která je zde lemována betonovým chodníkem (obr. 19), který pravděpodobně sloužil také k ostraze exponovaného úseku státní hranice. 


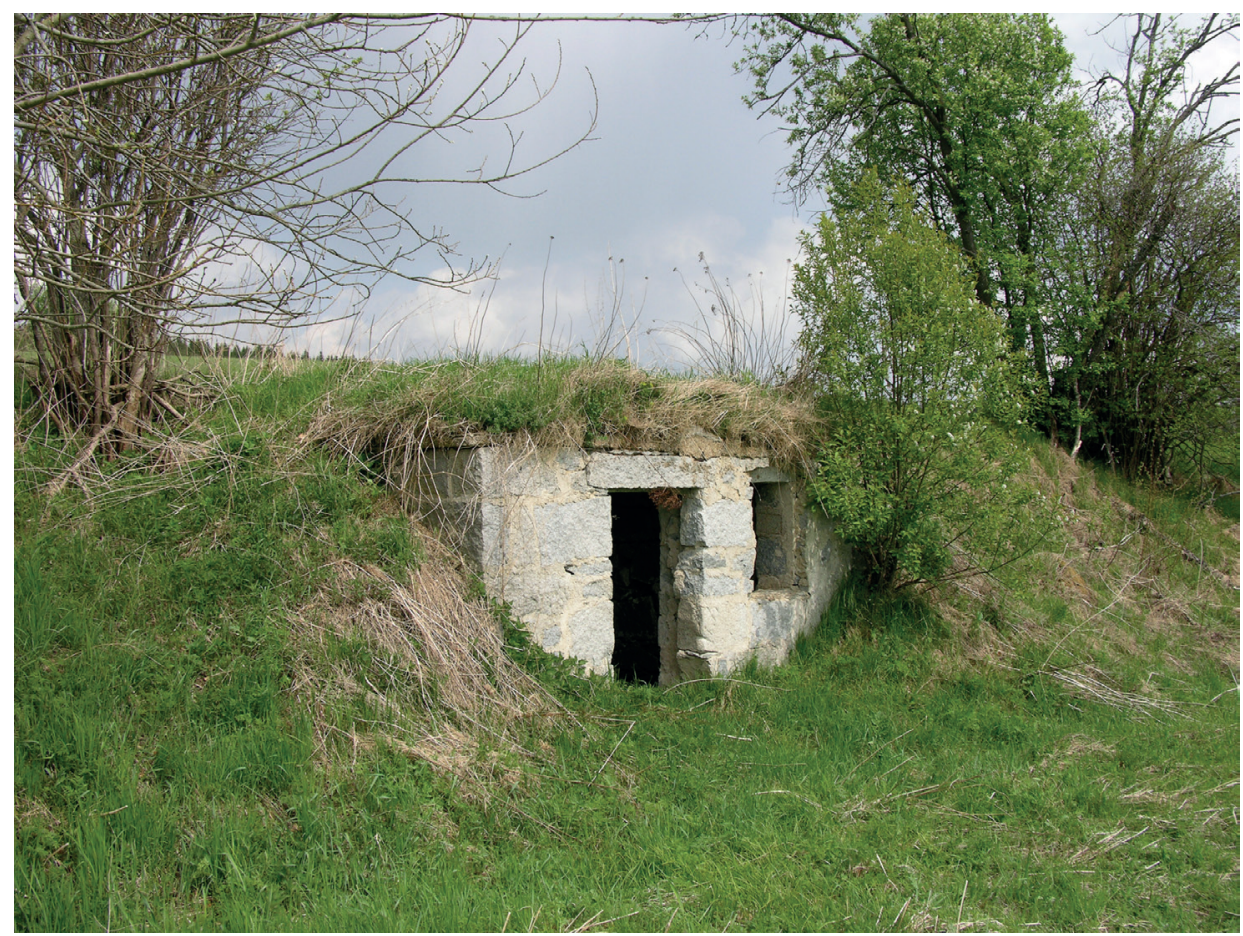

Obr. 18. Pozorovatelna pohraniční stráže zabudovaná do náspu nefunkční cesty v extravilánu vsi Lhota (foto M. Bureš, duben 2011).

Jako př́íklady vesnic, které přežily $\mathrm{v}$ zakázaném pásmu díky existenci vojenské posádky, mohou sloužit osada Žofín a městys Pohoří na Šumavě.

První zmínky o osadě s loveckým zámečkem, myslivnou a několika domy lze spojovat s přes údolí protilehlou osadou Javory. Lovecký zámeček byl vystavěn v letech 1854-1855 za Jiř́ího Buquoye mladšího (Úlovec 2005: 245-246). V roce 1930 se v osadě uvádí 5 domů s 19 stálými obyvateli (Statistický lexikon... 1934: 142). Díky svědectví pamětníků a jejich fotografické dokumentace se definitivně vyvrátily domněnky o zániku zámečku. Na rozdíl od často zveřejňovaného údaje o tom, že zámeček využívaný po roce 1945 jako rota Pohraniční stráže vyhořel (Úlovec 2005: 247), dokumentace jasně dokazuje, že vojska Ministerstva vnitra ČSR zdemolovala objekt, aniž by ho předtím zasáhla živelná katastrofa (obr. 20). Pohraniční stráž již zdevastovaný objekt nepotřebovala, protože se přesunula do nově vybudované základny v Černém údolí. Zároveň však využití zámečku Pohraniční stráží a jeho demolice až v 80. letech 20. století spolu s relativně větší vzdálenosti od státní hranice (cca $2 \mathrm{~km})$, znamenala přežití pro bezvýznamnou osadu s hájovnou a několika rekreačními objekty. 


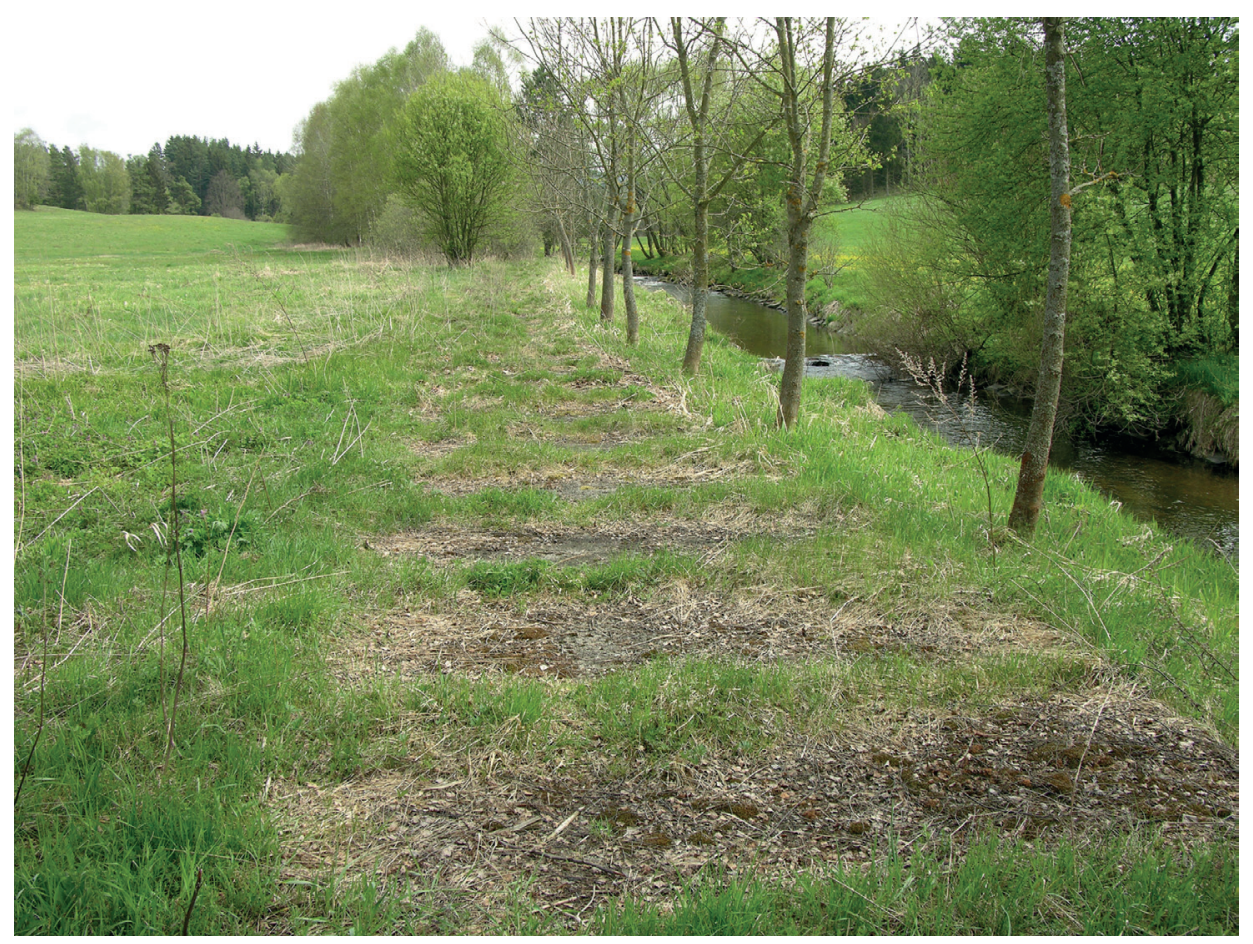

Obr. 19. Regulace Malše s betonovým chodníkem sloužící k ostraze státní hranice v bezprostřední blízkosti zaniklé osady Lhota (Neustift) a vsi Leopoldschlag Markt na druhé straně hranice (foto M. Bureš, duben 2011).

Pohoří na Šumavě je v současnosti patrně nejznámějším turistickým cílem Novohradských hor. V letech 1951 až 1979 z Pohoří zajišt'ovala ostrahu státních hranic rota Pohraniční stráže, jejímž sídlem byla někdejší kasárna Finanční stráže, které $\mathrm{v}$ třicátých letech vznikly $\mathrm{z}$ areálu někdejšího pivovaru na východním konci Pohoří. V sedmdesátých letech byl tzv. optimalizován prostor výčnělku hranice s Pohoř́ím a signální stěna ženijně technického zařízení ostrahy hranic byla přesunuta asi $7 \mathrm{~km}$ do vnitrozemí k Leopoldovu. Pohraniční stráž se přestěhovala na novou základnu v Černém údolí a civilní obyvatelé se postupně odstěhovávali do nově postavených bytovek v Pohořské Vsi. Podle některých pamětníků budova někdejší roty stála a chátrala i v následujících letech a byla pohraničníky jako majetek ministerstva vnitra pravidelně kontrolována ostatně jako další chátrající budovy vesnice. Budovy základny byly zdemolovány po roce 1983. Na leteckém snímku z roku 1983 je základna zachycena ještě v celém svém rozsahu pravděpodobně ještě i včetně strážní věže. Jediným pozůstatkem vojenského využití prostoru intravilánu Pohoří je 


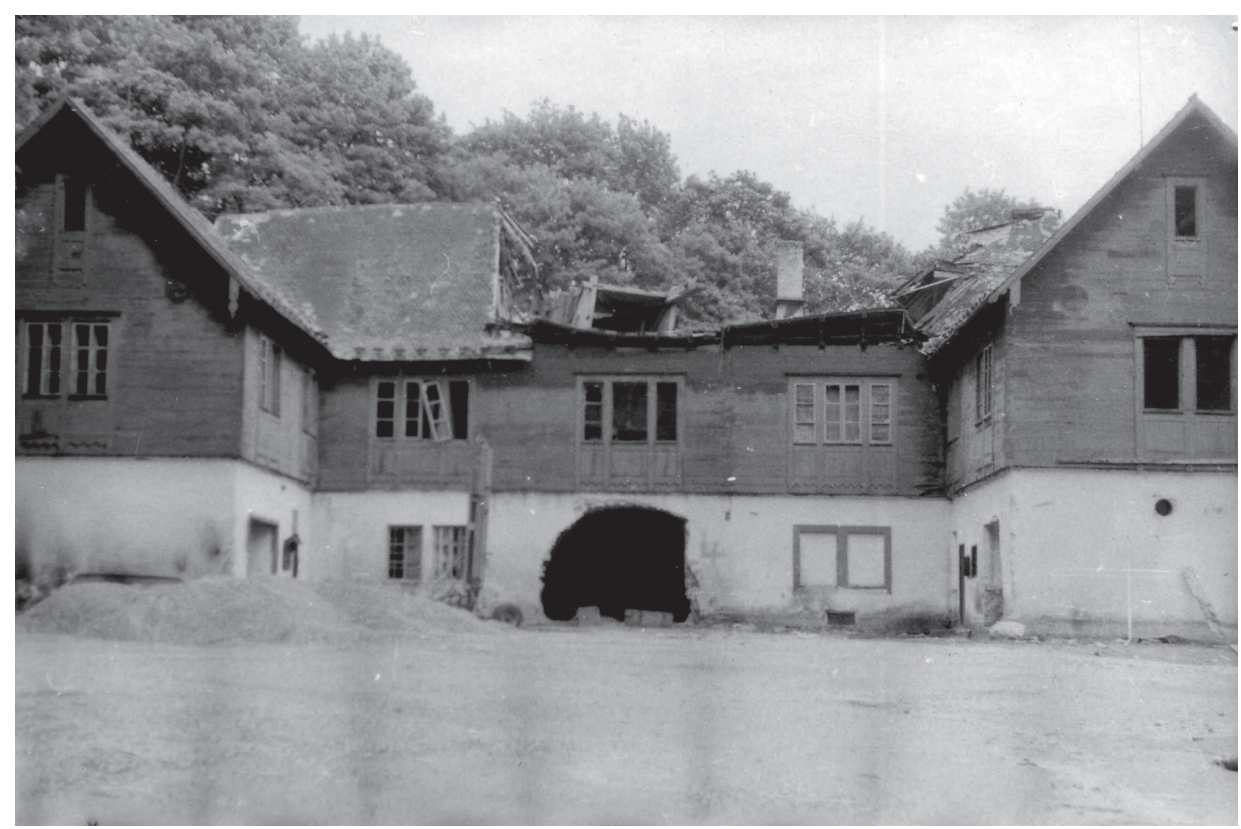

Obr. 20. Žofín (Sofienschloss), k. ú. Pivonice, lovecký zámeček využívaný Československou lidovou armádou v průběhu demolice v 1. pol. 80. let 20. století (foto Anonymus).

torzo pomníku postaveného u př́ležitosti společného výročí založení Pohraniční stráže a Komunistické strany Československa v roce 1976 (obr. 21). Tento pomník byl původně opatřený státním znakem ČSSR a nápisem vytvořeným z barevných zlomků pivních láhví připomínajícím 25. výročí založení Pohraniční stráže (1951) a 55 let od založení KSČ (1921). Kuriózní pomník byl původně situován v prostoru mezi kasárnami a tzv. Horní návsí. Pád Železné opony zastihl někdejší městys prázdný, zpustlý, ale alespoň z určité části nezdemolovaný (obr. 1). Existence významného, byt' polozř́iceného poutního kostela, spolu s geniem loci i povědomím o nedávné př́tomnosti lidské komunity, znamenala relativně rychlou regeneraci vesnice tentokrát do podoby rekreačního sídla (obr. 2).

\section{ŽELEZNÁ OPONA}

Počátek Studené války (cca. 1947-1989) znamenal pro jihočeské pohraničí poloviny 20. století vybudování ženijně technických zařízení pro zabezpečení hranic a zř́zení zakázaného a hraničního pásma, pro které se později vžilo označení „železná opona“. Tato situace vedla k dalšímu vysídlování, zániku sídel 


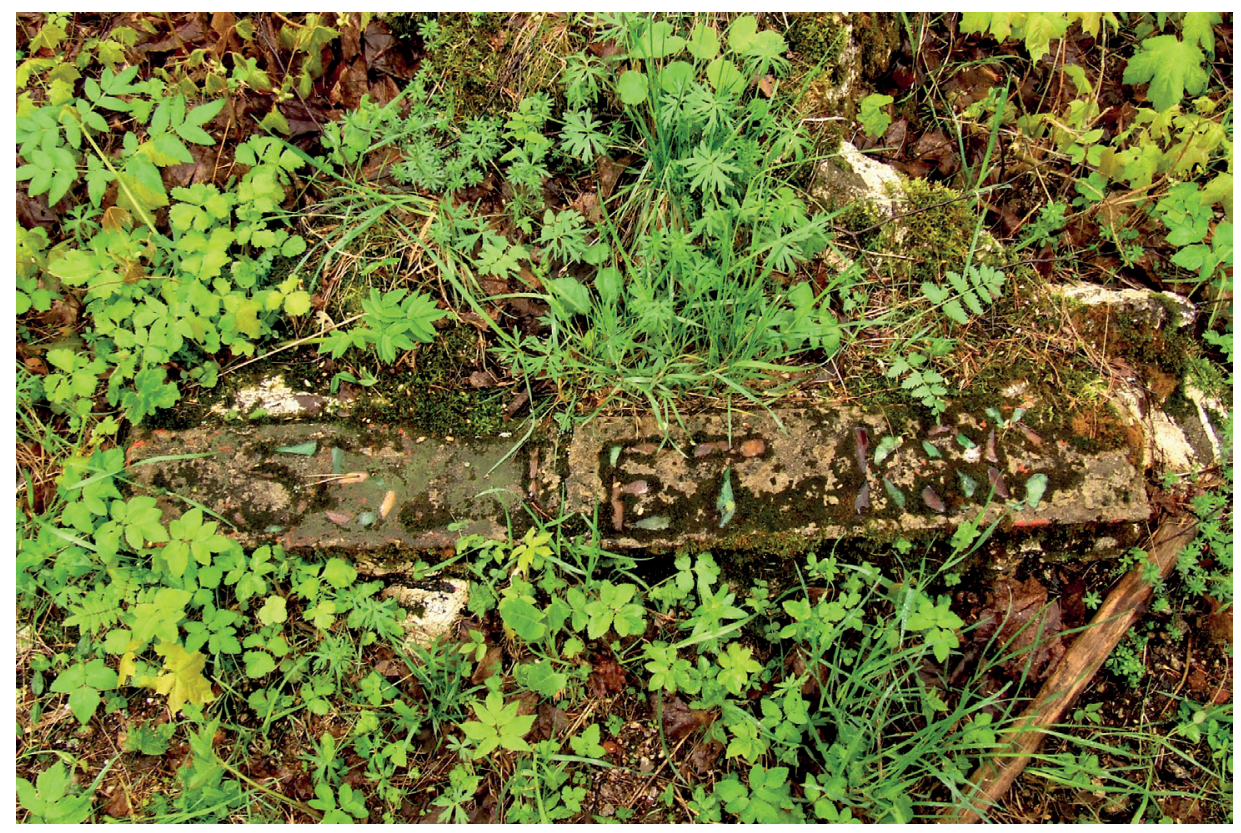

Obr. 21. Pohoří na Šumavě (Puchers), torzo pomníku postaveného u přiležitosti 25. výročí založení Pohraniční stráže a 55. výročí založení Komunistické strany Československa. Pomník byl původně situován v prostoru mezi kasárnami a tzv. Horní návsí (foto M. Bureš, květen 2011).

i ke změnám krajinného rázu. V roce 1951 komunistické orgány rozhodly zbudovat poblíže státních hranic se Západem průsek o šiřrce až 20 metrů, vztyčit ploty z ostnatého drátu a na exponovaných úsecích do nich pouštět elektrický proud (Jílek, Jílková 2006: 32). K budování, obsluze a střežení pohraničních ženijně technických zátarasů byly zřizovány základny Pohraniční stráže, at’ již v místech bývalých kasáren Finanční stráže nebo v intravilánech zrušených přihraničních obcí. Ženijně technické zátarasy byly doplněny o dřevěné pozorovatelny a další zařízení jako jsou střelnice či pikety (stálá předsunutá strážní stanoviště). Do obecného povědomí se tato pohraniční opatření dostala jako Železná opona.

Přesný průběh ženijních zátaras budovaných od sklonku roku 1951 je možno sledovat na kolmých leteckých snímcích počínaje snímkováním z roku 1952 (obr. 22) a pomocí georeferencovaných snímků získaných např. na portálu Cenia ${ }^{1}$ lze po korekcích provedených terénním průzkumem vynést jejich průběh do mapového podkladu (obr. 23 a 24). Uvedeným způsobem lze určit

\footnotetext{
${ }^{1}$ www.kontaminace.cenia.cz (navštíveno 11.08.2017).
} 


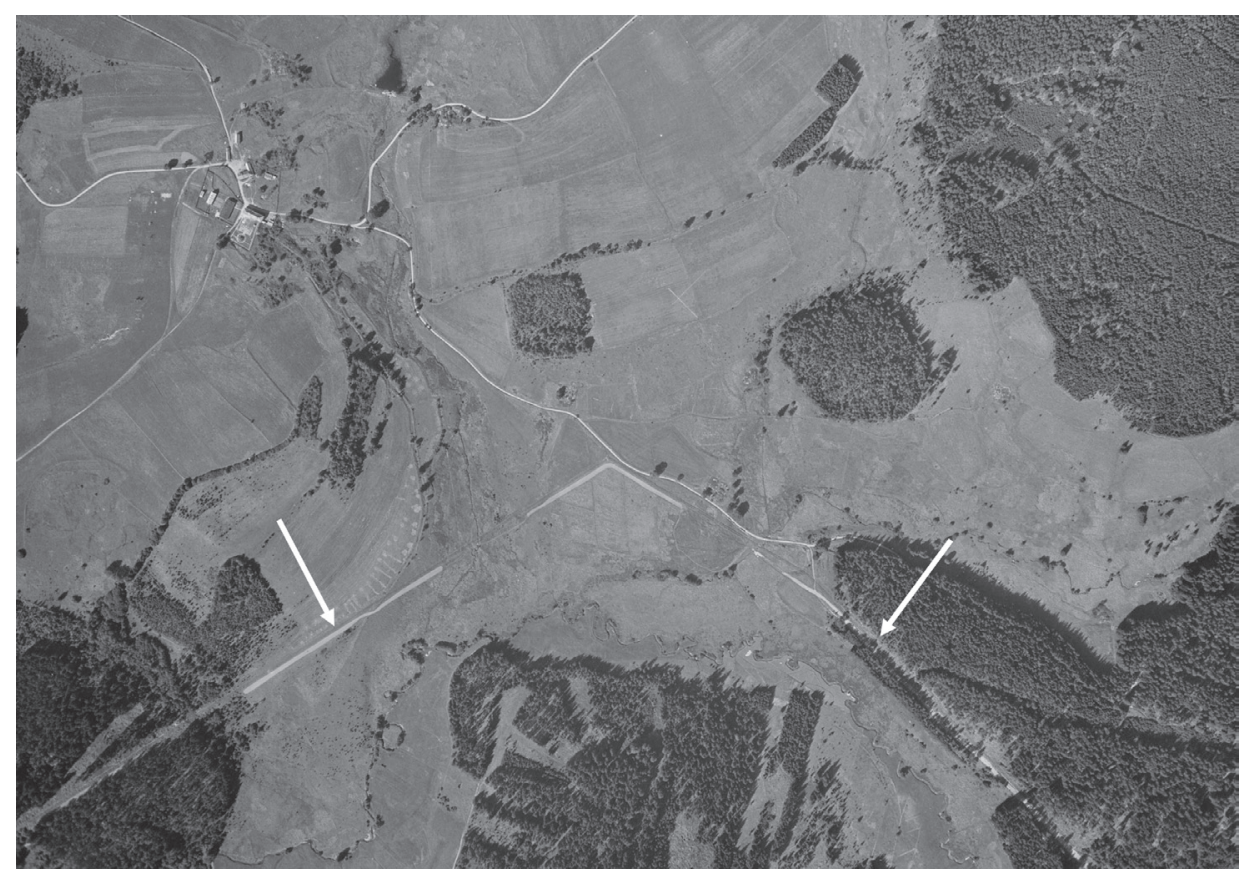

Obr. 22. Průběh linie ŽTZ první generace v bezprostřední blízkosti vsi Dolní Příbraní (Unter Sinetschlag) ve stejnojmenném katastru (http://www.kontaminace.cenia.cz/, navštíveno 11.08.2017).

průběh ženijních zátaras přesněji, než to je možné na základě dobových vojenských kartografických záznamů. Poblíž linie ženijně technických zátaras byly zřizovány základny pohraniční stráže (např. Cetviny, Dolní Př́braní, Ulrichov, Pohoří, Žofín), které někdy využívaly bývalých kasáren Finanční stráže (Pohoří), jindy byly pro pohraniční stráž přizpưsobeny někdejší zemědělské usedlosti (Cetviny, Ulrichov) či školy (Dolní Př́ibraní) nebo i lovecký zámeček (Žofín). Jelikož Pohraniční stráž byla spolu s Vojenskými lesy a statky jediným hospodářem na území, byly občasně využivány i další někdejší usedlosti $\mathrm{k}$ hospodářským účelům. Tyto hospodářské budovy se většinou nacházely v prostoru základen (např. Cetviny), ale výjimečně i mimo (např. Mikulov). Využití ozbrojenými složkami znamenalo pro tyto stavby fyzickou záchranu, která však byla limitována existencí Železné opony. Některé z vojenských základen zcela zanikly, nejčastěji přesunem ženijně technických zátaras hlouběji do vnitrozemí (Dolní Př́braní, Pohoří, Žofín). Nová linie zátaras budovaná od poloviny 60. let 20. století již nebyla napájena elektrickým proudem o vysokém napětí, ale hlavní součástí zátarasu byla tzv. signální stěna doplněná o nezbytný kontrolní pás zorané země, drátěné nášlapné překážky se signalizací, světlomety, betonové 


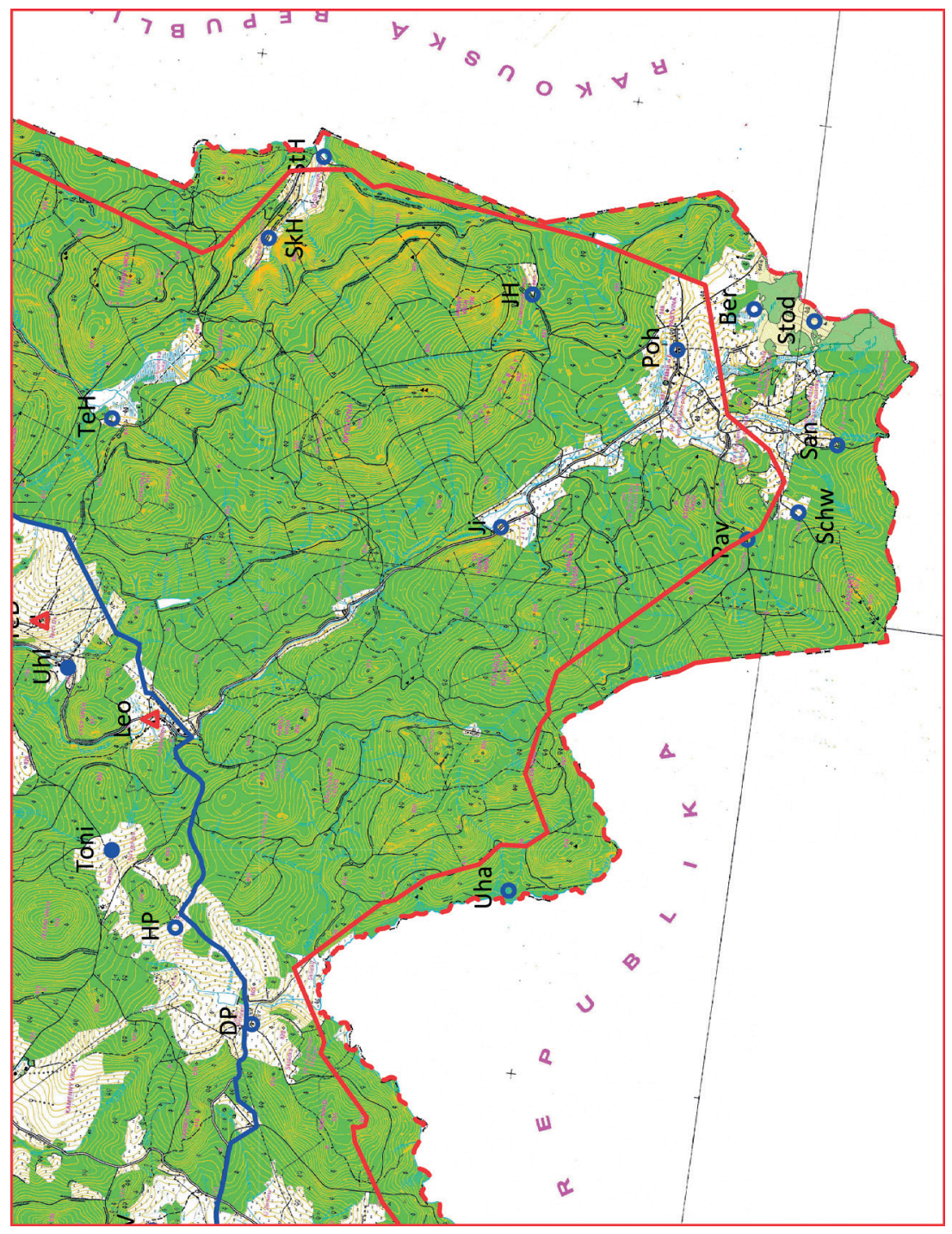




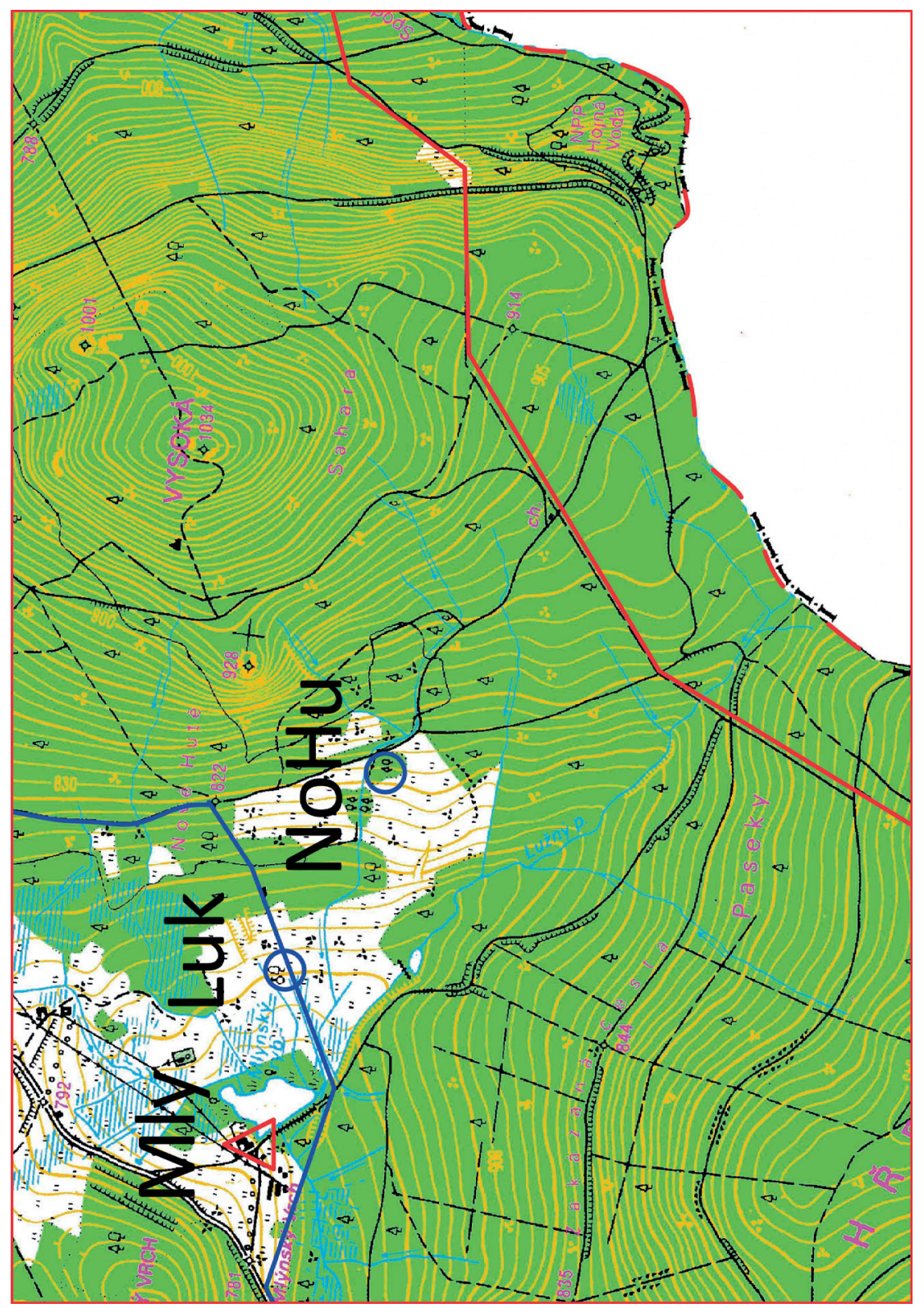


a železné ježky a další ženijní překážky. V osmdesátých letech se obvykle ženijně-technické zabezpečení skládalo ze dvou plotů, znemožňujících zvěři př́stup k prostřední tzv. signální stěně s elektrickým signálním zařízením (Jílek, Jílková 2006: 30-34).

Četné na povrchu dochované nálezy zachované $\mathrm{v}$ trase ženijně technických zábran dokládají původní účel těchto antropogenních útvarů (obr. 25, 26).

Některé základny Pohraniční stráže zanikly v uplynulých desetiletích beze zbytku jako Pohoří (např. Žofín), jiná vojenská zařízení, která sloužila svému účelu až do roku 1989, nebo ještě do počátku 90. let 20. století, se zachovala v torzu (např. Cetviny), nebo zůstala zachována a dnes slouží jiným než vojenským účelům (např. Černé Údolí, Svatý Kámen).

Průběh ženijně technických opatření pro ostrahu státní hranice obou dvou časových horizontů lze s větší či menší jistotou sledovat i na současných satelitních snímcích (obr. 27). Bez povrchového průzkumu nebo studia dalších kartografických pramenů zachycujících průběh ženijně technických zátaras lze často vegetační př́źznaky někdejších zátaras zaměnit s průseky, cestami apod. Lidarový snímek areálu zaniklých vesnic Nové Hutě a Lukov (obr. 28) obě linie nejen dobře zachycuje ve velkém měřítku, ale $\mathrm{v}$ detailu lze rozeznat i některé konstrukční prvky a tím jednoznačně odlišit relikty ženijně technických zátaras od cest a průseků pouze s využitím technik dálkového průzkumu země bez provedení terénního povrchového archeologického výzkumu (Bureš 2013: 221-227).

\section{ZMĚNa SíDelNíHo VZORCE NOVOHRADSKÝCH HOR A PODHŮŘí PO ROCE 1945}

Pro sledování vývoje zkoumaného území v daném období jsou důležité trojí hranice. Především se jedná o státní dříve zemskou hranici, která oddělovala Československo od Rakouska, respektive Českou zemi od Horních a Dolních Rakous. Další hranice, jejíž časová působnost je nepoměrně kratší, jsou ženijně technická zařízení budovaná do vzdálenosti dvou kilometrů od státní hranice v letech 1951 až 1952. Třetí hranicí, která měla zásadní vliv na vývoj zkoumané oblasti, je trasa ženijně technických zátaras z přelomu 60. a 70. let dvacátého století. Tato trasa se velmi přibližně kryje s hranicí tzv. hraničního pásma s omezeným přístupem vyhlášeným $\mathrm{v}$ padesátých letech, ale $\mathrm{v}$ části vymezené někdejším panstvím Nové Hrady také pravděpodobně přibližně s hranicí tzv. Horního hvozdu, jak byl Buquoyskou lesní správou nazýván zalesněný, až do sklonku 17. století neosídlený výběžek panství u zemské hranice. Je obecně známou skutečností, že ženijně technické zátarasy zbudované v různých obdobích podél hranic Československé socialistické republiky s Rakouskem a Spolkovou republikou Německo byly demontovány na počátku devadesátých let. Trasy obou časově na sebe navazujících ženijně technických zařízení byly pro Novohradské hory rekonstruovány (Bureš 2015). 


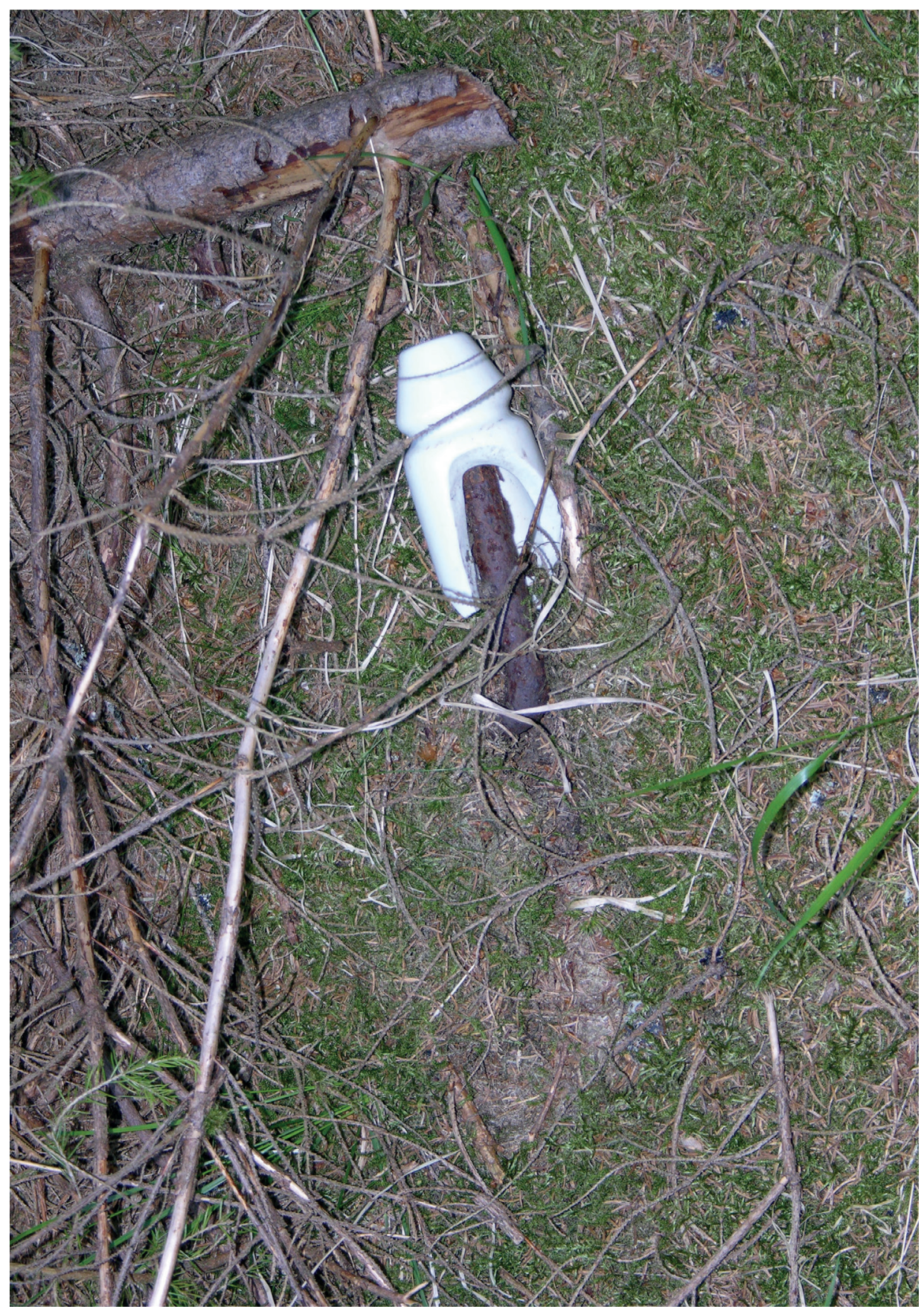

Obr. 25. Isolátor jako pozůstatek ŽTZ první generace z 50. let 20. století na katastru Pohoří na Šumavě (foto M. Bureš, květen 2011). 


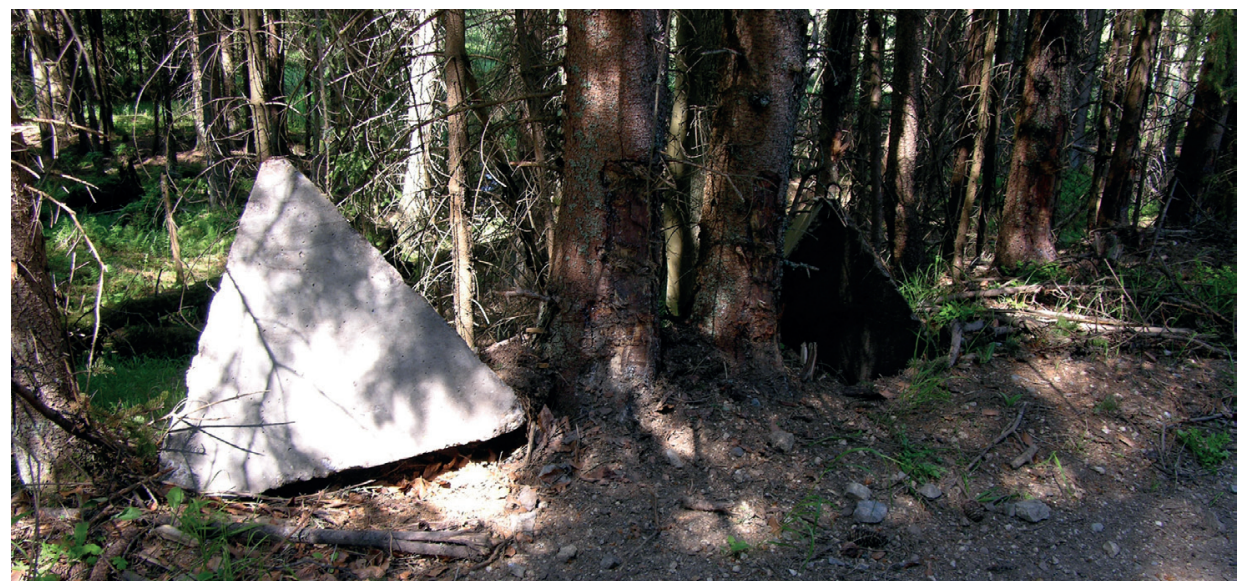

Obr. 26. Betonové protivozidlové jehlany sloužily většinou $\mathrm{k}$ přehrazení polních a lesních cest vedoucích napřr. napříč ženijně technickým zábranám. Na některých místech se z těchto cest zachovaly jen zábrany, které měly bránit jejich použití

(k. ú. Pohoří na Šumavě, foto M. Bureš, květen 2011).

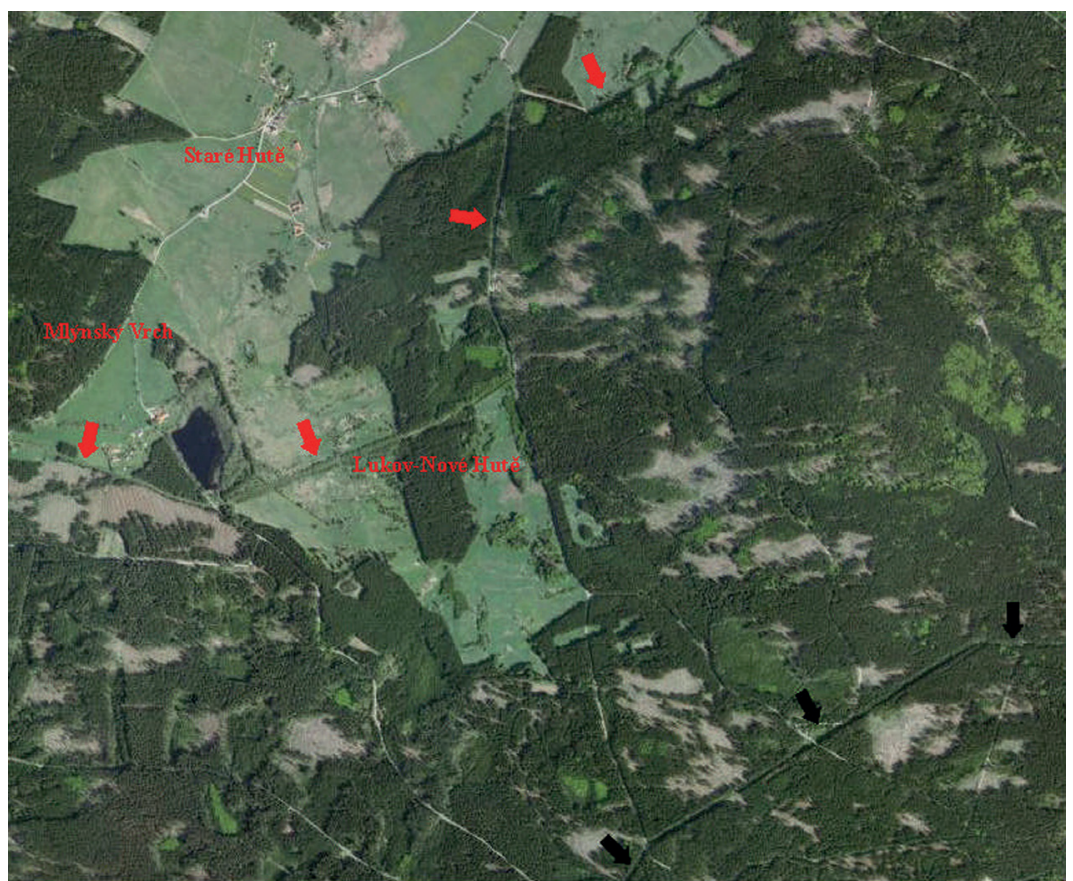

Obr. 27. Satelitní snímek prostoru zaniklých vsí Lukov (Luggau) a Nové Hutě (Neuhütten) na katastru Starých Hutí. Červenými šipkami označené porostové příznaky někdejších ženijně technických zábran druhé generace, černými šipkami průběh ženijně technických zábran prvé generace. 
Schematická mapa na obr. 29 zobrazuje stav osídlení před 2. světovou válkou a těsně po ní. Státní hranici s Rakouskem reprezentuje tučná přerušovaná čára na jihu, zatímco tenká přerušovaná čára vymezuje zkoumané území oproti vnitrozemí. Sídla jsou ve vymezeném území Novohradských hor a podhưř́i označena značkou ${ }^{2}$. Na mapce je sice patrná zřetelně nízká hustota sídel v hraničním pásmu, ale ta je daná vyšší nadmořskou výškou a vysokou mírou zalesnění (tzv. Horní Hvozd). Přibývající množství sídel na samých hranicích s Rakouskem v pozdejššim zakázaném pásmu je způsobeno napojením této pohraniční oblasti na zemědělská území rakouské strany Novohradských hor.

Mapka na následujícím obr. 30 zobrazuje stav cca v roce 1952, kdy byly podél hranice zdviženy ženijně technické zábrany znázorněné tenkou nepřerušovanou červenou linií. Další mapka na obr. 31 dokumentuje značně prořídlou sít' sídel kolem roku cca 1958. V zakázaném a hraničním pásmu jsou všechna sídla zaniklá, což by mohlo vést ke vzniku mylného dojmu, že lidská sídla zanikala především $\mathrm{v}$ oblastech přímo přiléhajícím $\mathrm{k}$ hranicím, což koresponduje $\mathrm{s}$ obecně přežívajícím klišé, že po vysídlení Němců nebyly vesnice u hranic dosidlovány a následně byly zdemolovány, aby krajina byla z hlediska vojenské kontroly pohybu nežádoucích osob přehlednější. Při pozorném studiu mapky (obr. 31) si nelze nevšimnout toho, že i ve vnitrozemí zaniká řada sídel, což naznačuje, že problém je složitější. Sídla v hraničním a příhraničním pásmu tak ve vnitrozemí zanikaly v podstatě ve srovnatelné míre. $\mathrm{K}$ depopulaci docházelo v jednotlivých pásmech nejen $\mathrm{v}$ poněkud odlišných obdobích, ale též z odlišných důvodů. Odsun obyvatelstva německé národnosti nebyl determinujícím faktorem, který zapř́ícinil definitivní opuštění sídel a změnu charakteru kraji-

${ }^{2}$ Sídlům byly v mapkách přiřazeny tyto značky: Blansko - Blan, Hradiště - Hrad, Mostky - Most, Dobechov - Dob, Květoňov - Kvet, Benčice - Ben, Drochov - Dro, Všeměřice - Vse, Rychnov nad Malší - RnM, U Svatého Kamene - UsvK, Dolní Dvořiště - DolD, Mladoňov - Mlad, Budákov - Bud, Mikoly - Miko, Obec - Ob, Tichá - Ti, Cetviny - Cet, Lhota - Lhot, Mikulov - Mik, Ličov - Li, Benešov nad Černou - NBen, Kamenice - Kam, Svatý Vít - SvV, Pohnholz - Pohn, Věrtele - Ver, Třebíčko - Tre, Nový Hamr - Ham, Černé Údolí - Cud, Hartunkov - Hart, Kuří - Kur, Velký Jindřichov - VJ, Čtyřdomí - Ct, Starý Holand - SH, Meziř́čí - Uhr, Velíško - Vel, Desky - Desk, Nové Stavení - Stav, Hanslův Mlýn - HM, Hodonice - Hod, Jaroměř - Jar, Bukovsko - Buk, Malonty - Mal, Bělá - Bela, Ludvické Hory - LuH, Rapotice - Rap, Jednoty - Toni, Uhliště - Uhl, Radčice - Rad, Dolní Př́braní - DP, Horní Příbraní - HP, Janova Ves - JV, Horní Malše - Uha, Leopoldov - Leo, Lužnice - Luz, Klepná - Klep, Jitronice - Jit, Polžov - Pol, Pohoří - Poh, Jiřice - Ji, Pavlína - Pav, Schwartzviertel - Schw, Šance - San, Stodůlecký Vrch - Stod, Beran - Ber, Janovy Hutě - JH, Stříbrné Hutě - StH, Skleněné Hutě - SkH, Pivonice - Piv, Pohorská Ves - PohoV, Terčí Dvưr - TeD, Terčí Hut' - TeH, Žofín - Zof, Javory - Jav, Zlatá Ktiš - Zlata, Rychnov u Nových Hradů - RNH, Meziluží - Melu, Chlupatá Ves - Chlup, Vesce - Ves, Bedřichov - Bed, Horní Stropnice - HorSt, Vyhlídky - Vyh, Světví - Svet, Dlouhá Stropnice - DloSt, Šejby - Sej, Konratice - Kon, Dobrá Voda - DoVo, Paseky - Pas, Hojná Voda - HoV, Malá Poustevna - Pou, Nové Hutě - NoHu, Staré Hutě - StaH, Lukov - Luk, Mlýnský Vrch - Mly. 


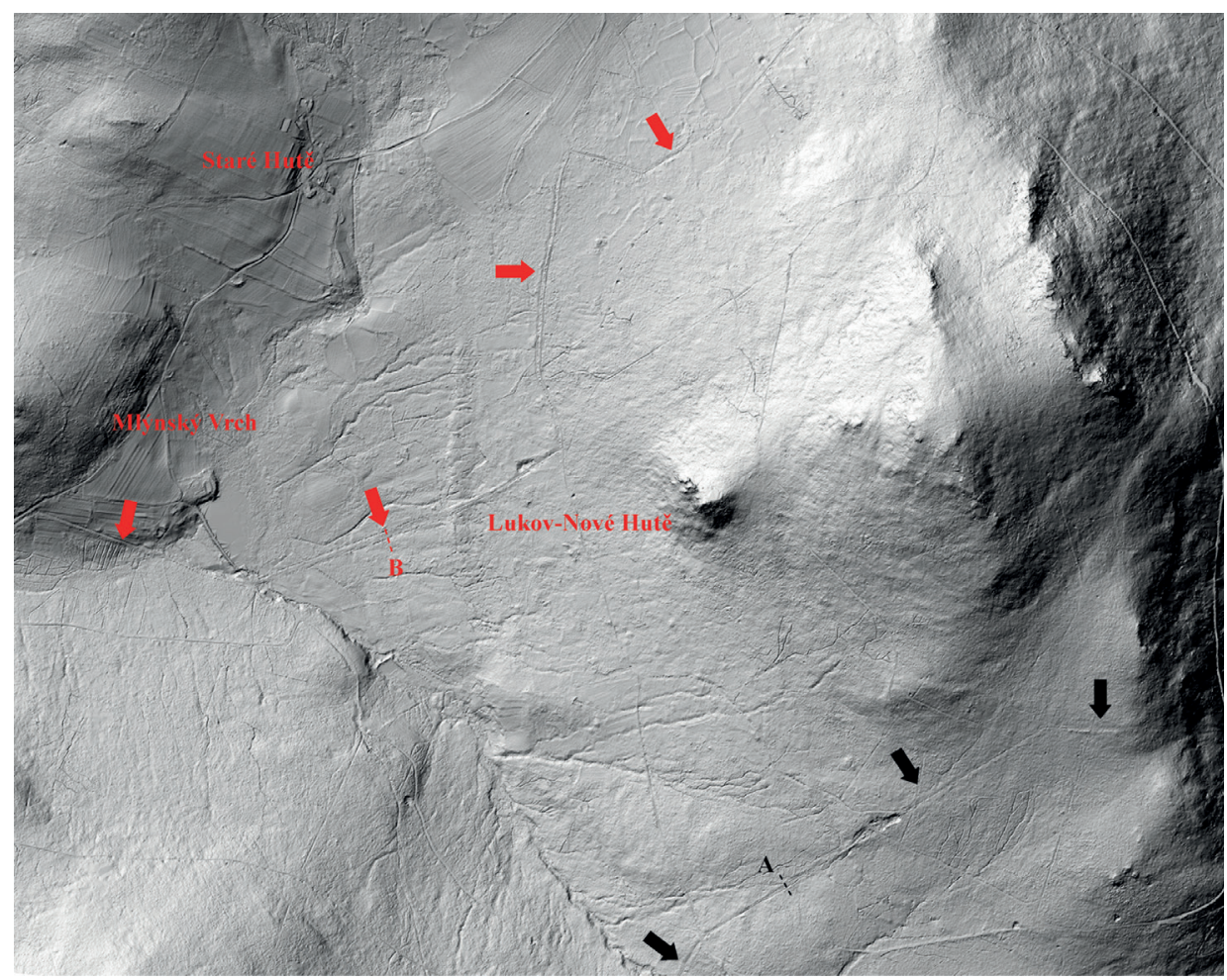

Obr. 28. Lidarový snímek prostoru zaniklých vsí Lukov (Luggau) a Nové Hutě (Neuhütten) na katastru Starých Hutí. Červenými šipkami označené terénní relikty někdejších ženijně technických zábran druhé generace, černými šipkami průběh ženijně technických zábran prvé generace.

ny, ale pouze jedním z více takových faktorů. Celá řada vesnic a osad zejména příhraničního, ale i hraničního pásma byla dosídlena, a i když dosídlenci různě migrovali, je možné předpokládat, že v některých místech zejména hraničního pásma s př́iznivějšími podmínkami $\mathrm{k}$ trvalému životu, by se migrace zastavila a došlo by ke stabilizaci, tak jak k ní došlo v řadě míst ve vnitrozemí. Před tím, než mohlo ke stabilizaci dojít, však bylo v letech 1951 až 1952 zř́izeno tzv. zakázané pásmo, které bylo na vnitřní straně opevněno ženijně technickými zábranami pod vysokým napětím. Osídlené vesnice, které ležely v prostoru zakázaného pásma, byly násilně vysídleny.

V hraničním pásmu byla provedena selekce obyvatelstva podle politických kritérií, byl omezen jeho pohyb a snížilo se množství pracovních př́ležitostí a možností uplatnění. Změna způsobu obývání hraničního pásma spolu $\mathrm{s}$ těžšími životními podmínkami $\mathrm{v}$ isolovaných osadách $\mathrm{v}$ lesích vedla $\mathrm{k}$ da- 


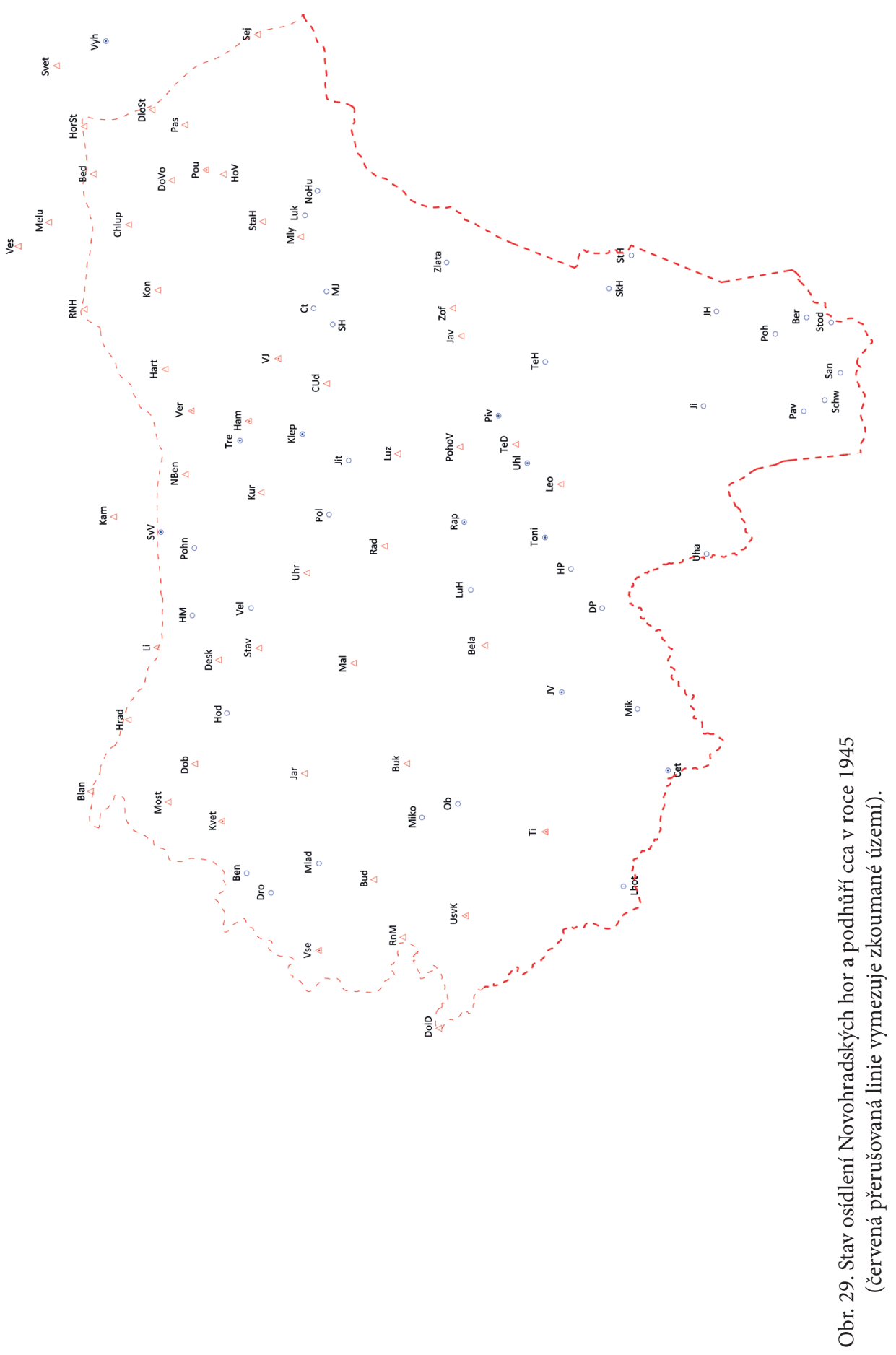




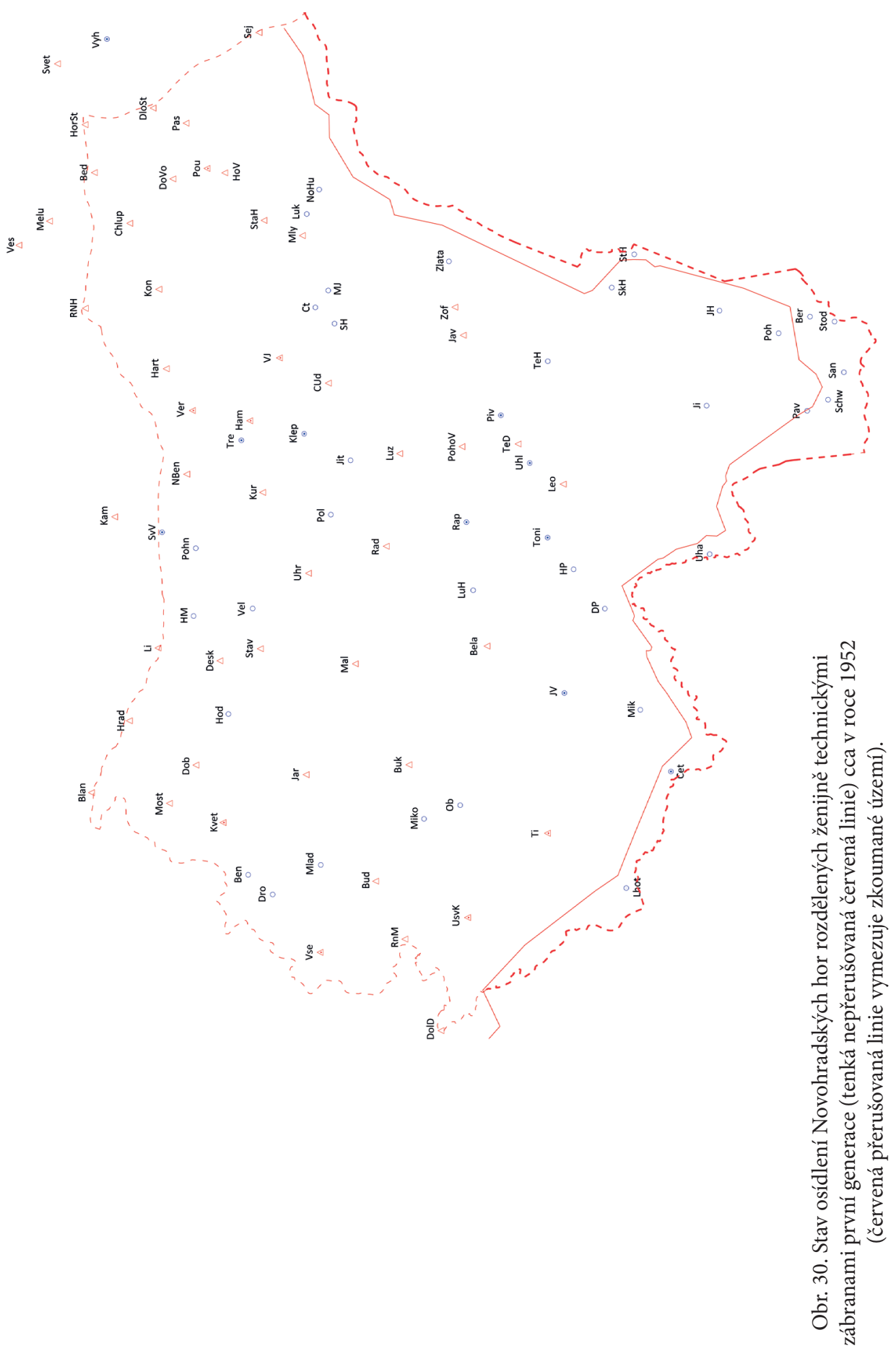




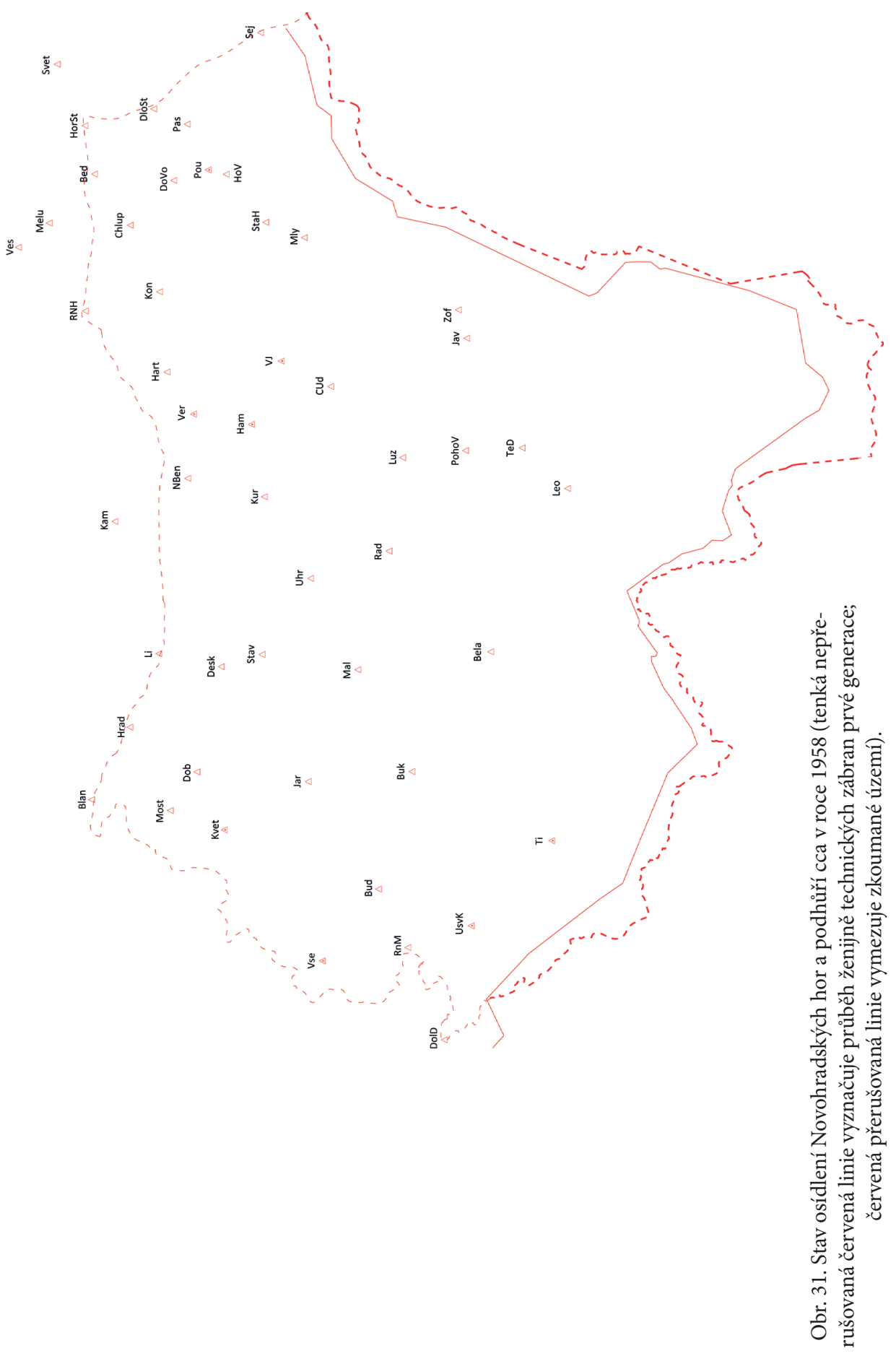


lšímu odlivu obyvatelstva, které bylo umocněno i přetrvávajícím dostatkem volných nemovitostí hlouběji ve vnitrozemí. Osídlená v poslední fázi v druhé polovině 60 . let 20 . století zůstala jen vesnice hraničního pásma, kde obživa byla do značné míry vázána na vojenskou posádku (Cetviny, Pohoří na Šumavě, Javory). V momentě, kdy bylo takové místo posádkou opuštěno, odešlo i civilní obyvatelstvo (Pohoří na Šumavě). Budování ženijně technických zábran první poloviny sedmdesátých let 20 . století tak nemuselo být spojeno s vysídlováním obyvatelstva. Linie ženijně technických zátaras druhé generace (obr. 32) byla vedena po hranici osídleného území, což dokazuje výrazné přiblížení $\mathrm{k}$ hranicím v místech trvale osídlených jako je prostor Dolního Dvořiště, kde byl ovšem hraniční přechod, a především prostor Šejb na východě zkoumaného území. Praktické národohospodářské důvody tak převážily nad státně bezpečnostními aspekty.

K odlišnému vývoji došlo ve vnitrozemí sledovaného území. Přestože dosídlenců bylo podstatně méně než původního obyvatelstva, archeologický výzkum prokazuje, že většina zemědělských osad byla dosídlena. Ve vesnicích s kompaktním jádrem (např̀. Hodonice) i v osadách s roztroušenou zemědělskou zástavbou (napřs. Svatý Vít) výzkum potvrzuje, že byly dosídleny jen některé usedlosti $\mathrm{v}$ závislosti na tom, jak dosídlencům bylo přidělováno více půdy, než původně náleželo $\mathrm{k}$ jednotlivým usedlostem. Jak v roztroušené zástavbě, tak v kompaktních jádrech byly přednostně dosídlovány dobře položené větší usedlosti - dvory, zatímco chalupy byly ponechávány samovolnému postupnému rozpadu (např. Hodonice). Po roce 1948 však byla půda zemědělským dosídlencům postupně odebírána a zemědělství bylo kolektivizováno. Bez vlastní půdy se snížila možnost se slušně uživit bez závislosti na pochybném výkonu ostatních družstevníků. Nejlepší hospodáři, pro které byla zemědělská půda to hlavní, kvůli čemu do oblasti přišli, když jim byla odebrána, zase odešli. Postupující socializace zapříčinila úpadek řemesel a místních služeb (srov. Stehlík: 2001: 109-123). Odchod největších hospodářủ vyvolává další vlnu vnitřní migrace. Obyvatelé, kteří zůstali, znovu opouštějí své usedlosti a stěhují se do stavebně technicky zachovalejších domů, které se uvolnily odchodem hospodářu. Do takových dvorů se často někdy dočasně někdy trvale umist'ují provozovny Jednotných zemědělských družstev, posléze Státních statků. Opuštěné chalupy a dvory jsou rozebírány přežívajícími sousedy i obyvatelstvem vzdálenějších vesnic a osad. V období přetrvávajícího nedostatku padesátých let se hodí vše, co lze transportovat: vybavení, stavební materiál, dřevo na otop. Tak, jak se koncentruje kolektivizovaná zemědělská výroba, tak zbylé obyvatelstvo redukuje stavební podobu zbývajících usedlostí pouze na obytnou část $-\mathrm{z}$ někdejších dvorů se stávají chalupy, nebo se, a to $\mathrm{v}$ převažující míree, stěhuje do míst centralizované zemědělské výroby. Zdá se, že čím blíže byla zanikající vesnice k jiné vesnici se 


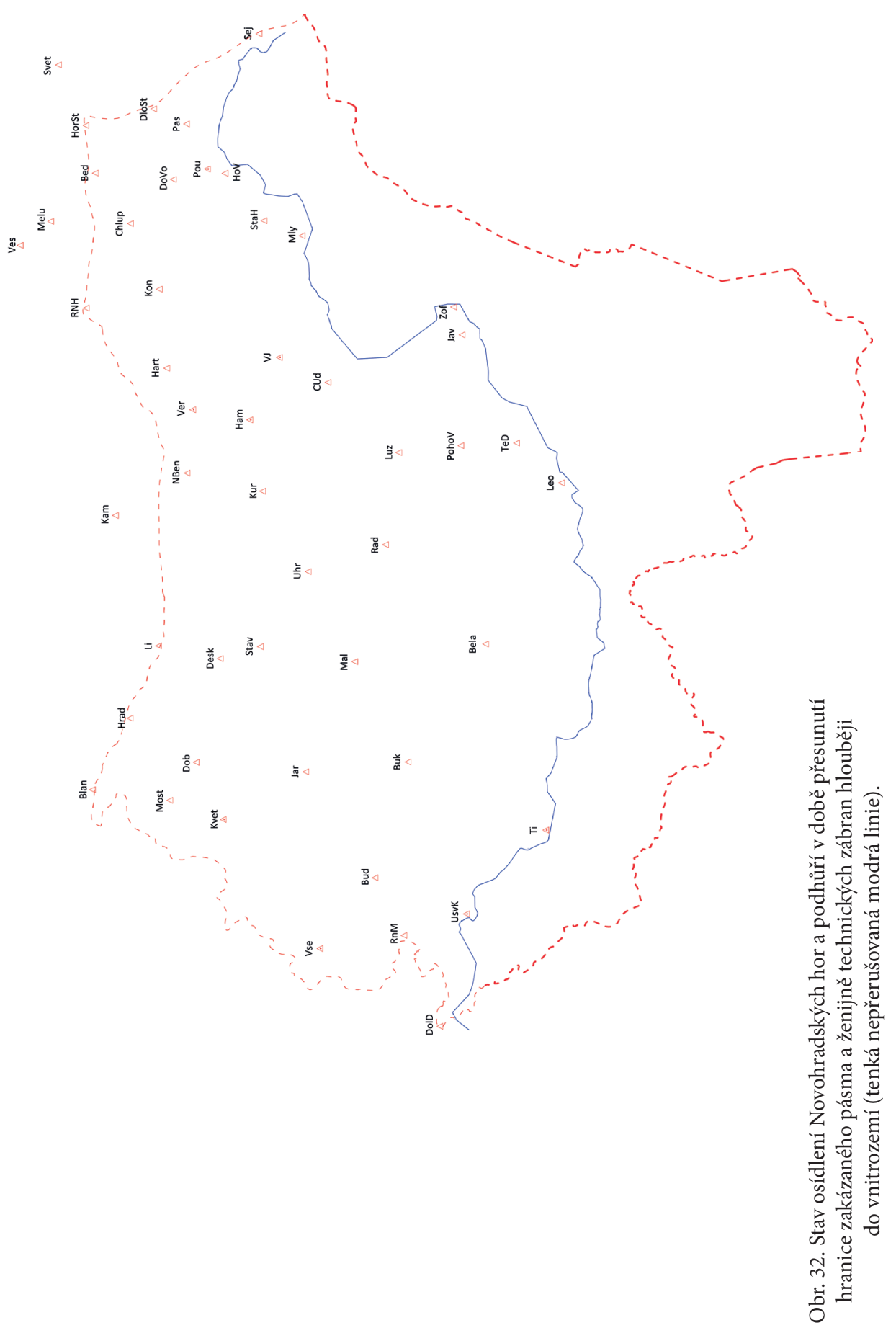


zemědělským provozem, tím rychleji zanikala (např. Velíško). Naopak tam, kde centrum zemědělské výroby bylo daleko, bylo třeba udržovat nějaké provozy jako detašované, a proto se tam delší dobu udrželo i obyvatelstvo (např. Hodonice, Obec, Drochov). V momentě, kdy se kapacity např. pro ustájení dobytka nebo skladování píce ve střediscích zemědělské výroby staly dostatečnými, nebylo již zapotřebí ani odloučených provozů. Navíc se vzrůstajícími možnostmi zemědělské mechanizace bylo možno obdělávat čím dál odlehlejší pozemky bez toho, aby byl v místě nějaký trvale žijící zemědělský personál. Veškerá infrastruktura se soustředila do středisek zemědělské výroby, v odlehlejších vesnicích nebyly školy, obchody, služby ani další pracovní př́ležitosti. Nedostupná byla hromadná doprava a nevyhovující byly i místní komunikace. Po vystěhování posledních obyvatel následuje další rozebírání završené demolicemi. Demolují se především usedlosti a celé vesnice, které byly v blízkosti jiných žijících sídel nebo takové, které byly viditelné z hlavních i vedlejších silničních tahů. Zapadlé osady a usedlosti byly ponechány samovolnému postupnému rozpadu a časem zarostly náletovým lesem a jinou vegetací.

\section{ZÁVĚR}

Příspěvek spolu s dřívější podrobnější studií na obdobné téma (Bureš 2015) ukázal, že zánik lidských sídel v celém území Novohradských hor a podhưứí nelze jednoznačně spojovat jen s odsunem obyvatelstva německé národnosti ani pouze se zř́izením ženijně technických zábran podél státní hranice a vznikem tzv. zakázaného pásma. Svoji roli sehrála i změna hospodářských poměrů, zejména kolektivizace zemědělství a zánik drobných živností vedoucí k postupnému zániku použitelné infrastruktury. To vše vedlo k dlouhodobé depopulaci, kterou se dodnes nepodařilo zvrátit. V době centrálně rízené ekonomiky nevyužívání potenciálu území, jehož hospodářský prínos byl ještě v dobré paměti, znamenalo značný politický problém, který bylo nezbytné ideologicky ospravedlnit a fakticky zamaskovat. Zř́zení tzv. zakázaného a hraničního pásma se mohlo hodit k zneviditelnění jednoho velikého politického neúspěchu. Zakrývat zbídačelé pohraničí bylo třeba stejně tak před vnějším i vnitřním nepř́itelem. Oba ho mohli využít v „,nepřátelské“ propagandě. Jednorázová destrukce stavby čili demolice byla v době po roce 1951 nejběžnějším způsobem zániku lidských př́ibytků postižených depopulací. Přednostně zdemolovány byly objekty, které byly viditelné z osídlených míst rakouského př́hraničí (např. Stodůlecký Vrch, Beran, Lhota aj.), př́ipadně neosídlené a zchátralé objekty v částečně obydlených vesnicích. Následovaly prázdné samoty a celé vesnice, které byly v blízkosti osídlení nebo viditelné z funkční vesnice nebo z nějaké civilním obyvatelstvem využívané komunikace (např. Jiřice, Mikulov, Polžov, Velíško aj.). Naopak ob- 
jekty, které byly nepř́istupné a nebyly viditelné okem civilního pozorovatele domácího nebo zahraničního, byly ponechány samovolnému rozpadu (např. hostinec U alpské vyhlídky pod Kamencem, vsi Obec, Mladoňov aj.). Samožrejmě, že existují výjimky, anebo př́ípady, kde se např. viditelnost dnes těžko posuzuje. Nevyřčený úkol komunistické propagandy zmanipulovat historické vědomí a nechat lid zapomenout na živoucí pohraničí, se ovšem téměř bez výjimky povedl (srov. Holtorf, Williams 2006: 234-254). Dnešní turisté obdivují divočinu i př́rodní prostředí zachované díky dlouholeté existenci zakázaného pásma, aniž by si i přes povědomí o někdejším německém osídlení dovedli vůbec jen představit, že před časem nepřesahující délku trvání jednoho lidského života, byla zdejší krajina daleko podobnější kulturní krajině kdesi v srdci české kotliny než té dnešní.

Michal Bureš

Archeo Pro o.p.s.,

e-mail: michal.bures@archeo4u.cz

\section{LITERATURA}

\section{Prameny}

Statistický lexikon... (1934), Statistický lexikon obcí v Republice Československé vydán ministerstvem vnitra a Státním úr̆adem statistickým na základě výsledků sčitání lidu z 1. prosince 1930, Praha.

Statistický lexikon... (1955), Statistický lexikon obci Republiky Československé 1955. Podle správního rozdělení 1. ledna 1955, sčitání lidu a domů a bytů 1. března 1950, Praha.

Statistický lexikon... (1966), Statistický lexikon obci ČSSR. Podle správního rozdělení 1. ledna 1965, sčitání lidu, domů a bytů 1. března 1961, Praha.

Statistický lexikon... (1976), Statistický lexikon obcí ČSSR 1974. Podle správního rozdělení k 1. lednu 1974, sčitání lidu, domů a bytů k 1. prosinci 1970, Praha.

Vojenský geografický a hydrometeorologický úrad v Dobrušce, letecké měřičské snímky: 2439/1947, 02076/1967, 06540/1949, 14618/1958, 02059/1967, 12168/1983.

Zemépisný lexikon ČR... (1991), Zemépisný lexikon ČR. Obce a sídla N-Ž. Stav k polovinè 80. Let, Praha.

\section{Literatura}

Buchli V., Lucas G. (2001), Archaeologies of the Contemporary Past, Routledge, Abingdon.

Bureš M. (2013), Odraz Železné opony v datech leteckého laserového skenování na př́kladu Novohradských hor, [in:] M. Gojda, J. John a kol., Archeologie a letecký lidarový pri̊zkum krajiny, FFZČU, Plzeň, pp. 221-227. 
Bureš M. (2015), Vesnice zaniklé po roce 1945 a kulturní Krajina Novohradských hor, Západočeská univerzita v Plzni, Plzeň.

Bureš M., Pařez J. (2006), Plavení dřeva, [in:] V. Dudák (ed.), Novohradské hory a novohradské podhưrí, Baset, Praha.

Harrison R., Schofield J. (2010), After Modernity: Archaeological Approaches to the Contemporary Past, Oxford University Press, Oxford.

Holtorf C., Piccini A. (eds.) (2011), Contemporary Archaeologies: Excavating Now, Peter Lang, Frankfurt am Main.

Holtorf C., Williams H. (2006), Landscape and memories, [in:] D. Hicks, M.C. Beaudry, Historical Archaeology, Cambridge University Press, Cambridge, pp. 234-254.

Jílek T., Jílková A. a kol. (2006), Železná opona. Československá státní hranice od Jáchymova po Bratislavu 1948-1989, Baset, Praha.

Klír T. (2008), Osídlení zemědělsky marginálních půd v mladším středověku a raném novověku (= Dissertationes Archaeologicae Brunenses/ Pragensesque 5), Univerzita Karlova, Praha.

Matoušek V. (2000), Graffiti ve světle archeologie. Př́spěvek k diskusi o archeologii současnosti, ,Cargo“ 2(1), pp. 4-17.

Mayerová F., Vašíček Z. (2004), Minulost a současnost, pamět’ a dějiny, „Soudobé dějiny“ 11, p. 27.

Neustupný E. (2007), Metoda archeologie, Aleš Čeněk, Plzeň.

Neustupný E. (2010), Teorie archeologie, Aleš Čeněk, Plzeň.

Neustupný E. (2013), Archeologie modernity - teoretický kontext, [in:] P. Vařeka (ed.), Archeologie 19. a 20. století. Př́stupy-metody-témata, Západočeská univerzita v Plzni, Plzeň, pp. 13-16.

Rotschild N.A., Mills B.J., Ferguson T.J., Ferguson T. J., Dublin S. (1993), Abandonment at Zuni fading villages, [in:] C.M. Cameron, S.A. Tomka (eds.), The Abandonment of Settlements and Regions. Ethnoarchaeological and Archaeological Approaches, Cambridge University Press, Cambridge, pp. 123-137.

Řezníčková Z. (2006), Mistopis, [in:] V. Dudák (ed.), Novohradské hory a novohradské podhưrí, Baset, Praha, pp. 283-320.

Schiffer M.B. (1996), Formation Processes of the Archaeological Record, University of Utah Press, Salt Lake City.

Stehlík M. (2001), Staré Město pod Landštejnem 1945-1960. Př́běh jihočeského pohraničí, „Jihočeský sborník historický“ 69-70, pp. 109-123.

Tomka S.A., Stevenston M.G. (1993), Understanding abandonment processes: summary and remaining concerns, [in:] C.M. Cameron, S.A. Tomka (eds.), The Abandonment of Settlements and Regions. Ethnoarchaeological and Archaeological Approaches, Cambridge University Press, Cambridge, pp. 192-193.

Úlovec J. (2005), Zaniklý zámek Žofin, ,Výběr“ 42, pp. 245-254.

Ústav pro soudobé dějiny Akademie věd České republiky, Praha, ÚSD 2000.

Vařeka P. (ed.) (2013), Archeologie 19. a 20. století. Př́stupy - metody - témata, Západočeská univerzita v Plzni, Plzeň. 
Vilímek T. (2014), Specifika soudobých dějin, [in:] J. Čechurová, J. Randák a kol., Základni problémy studia moderních a soudobých dějin, NLN a Univerzita Karlova v Praze, Praha, p. 172.

\section{Internetové zdroje}

http://www.bwb-ooe.at/ (navštíveno 28.05.2016).

http://www.kontaminace.cenia.cz/ (navštíveno 11.08.2017).

\section{SUMMARY}

\section{ARCHAEOLOGY OF THE CONTEMPORARY PAST OF THE NOVOHRADSKÉ MOUNTAINS AREA}

This work covers the area of the Novohradské Mountains and their foothills in the South-Bohemian Region, near the Czech-Austrian border. The examined area is demarcated by the following settlements and other landmarks; Šejby (Scheiben) - Dlouhá Stropnice (Lang Strobnitz) - Horní Stropnice (Strobnitz) - Rychnov u Nových Hradů (Deutsch Reichenau) - Benešov nad Černou (Deutsch Beneschau) - Ličov (Litschau) - Hradiště (Radischen) - Blansko (Pflanzen) - the Malše River (Maltsch Bach) before Kaplice (Kaplitz) and then along the Malše River (Maltsch Bach) towards Dolní Dvořiště (Unter Heid) to the border with Austria and along the border line to the village of Šejby (Scheiben); it covers a significant area of the Kaplice, Benešov and Nové Hrady regions. It includes 39 cadastral areas extending over an area of $282 \mathrm{~km}^{2}$.

The research focused on the villages that ceased to exist after 1945. After World War II, the researched area was affected by a significant decrease in population as a consequence of the expulsion of former Czechoslovak citizens of German nationality, who represented a majority population prior to 1945, and as a result of subsequent economic and social changes, they related mainly to the collectivization of villages.

The examined area of the Novohradské Mountains and the defined period are characterized by a great degree of abandonment and decay; in some places it was followed by reuse and regeneration, while in others it met with extinction. Continuity and uninterrupted use of an area by a single community, be it autochthonous Czechs or Germans who were not expelled, is rarely found.

To distinguish between different cases, various degrees of extinction have been defined based on the extent of the exit transformation these areas and their components underwent (or did not undergo, as the case may be). Cultural post-depositional transformations include razing to the ground, re-cultivation, afforestation, farming soil amelioration, forest amelioration, ploughing and construction. Natural post-depositional transformations include gravitation and water erosion as well as the effects of vegetation. Post-depositional transformations are directly related to both the current and the past uses of the area. 
The basic unit of the research of the extinct villages in the Novohradské Mountains is the component, an analytical unit of the sources that can be used to describe broader settlement areas. The spatially related components that were in the past produced by a community define a broader settlement area (i.e. settlements, villages, small towns, including relevant farming and non-farming areas and facilities).

Within the examined territory, a field survey yielded 95 broader settlement areas, of which 41 can be described as fully functional in terms of existing and fully functioning communities, 9 are partially functional with some communal activities still being present, 11 are non-functional and used for other than community purposes, such as recreation or storage and 34 are entirely extinct.

The work studies and compares mutual spatial relations between the components, the types and forms of exit transformations, the types of post-depositional transformations and both past and current uses of the area of the components. The focal point is an examination of the gradual abandonment, which led to extinction, the course of exit transformations and, subsequently, the effect of post-depositional transformation impacts, both cultural and natural.

The analysis allowed for a comparison of the components within one broader settlement area, or for a comparison of the analysis results in the areas with similar data and development structures. However, for objective reasons, there are only few such cases - the development of the individual areas was rarely stereotypical and, with a few exceptions, it instead demonstrated highly individual features. Secondly, the choice of the areas to be analysed in detail was motivated by an effort of the individual studies to cover a maximum number of the types of development in the surveyed territory. It is therefore rather problematic to arrive at a synthesis based on the outcomes of the individual studies in the surveyed area. For instance, it was not possible to confirm the assumption that the relics of the transformed settlements were better preserved in the inland than in the border areas, where they were more thoroughly demolished for strategic reasons. The research suggests that the strategic perspective was merely one of many reasons, as often the case - the initiative of a military commander or perhaps other subjective reasons played a decisive role here. Somewhat paradoxically, the relics of the houses in the wooded areas near the border, where they were demolished only to the height of the parapet, were better preserved than the relics recorded in the rural inland, where they could be reclaimed for economic reasons. The well documented and thoroughly examined areas, however, rendered sufficient amounts of information for a microanalysis (such as Velíško - Wölschko, Pohoří - Puchers), allowing for not only a description of the mechanisms of the exit transformation and post-depositional transformations, but also reasons for and the approximate time of these processes.

Three types of borders play an important role in the examination of the development of the surveyed area in the defined period of time. First and foremost it is the state border, previously known as the Land border, which separated Czechoslovakia from Austria or Bohemia from Upper and Lower Austria. The second border, whose lifespan was by far shorter, is represented by the border barrier system constructed within two kilometres from the state border between 1951-1952, while 
the third border, which significantly affected the development of the surveyed area, is the line of border barrier system originating at the turn of the 1960s and 1970s. This border approximately overlaps with that of the "border zone with the limited access" established in the 1950s, but in the section delimited by the former Nové Hrady - Gratzen demesne, it probably approximately overlaps with the borderline of the "Upper Forest" as well, as the forested protrusion of the demesne near the Land border, unpopulated until the late 17th century, was drawn by the Buquoy forestry office. As is generally known, the border barrier systems built at different times along the border of the Czechoslovak Socialist Republic with Austria and the Federative Republic of Germany were dismantled in the early 1990s. The routes of both of these border barrier systems, whose construction followed in close succession, were, for the purposes of this work, reconstructed, making use of historical aerial photographs (the route built in the 1950s) and contemporary satellite photographs (barrier systems which were part of the border guard system through 1989). Some information is based on the observations made during the field survey. The maps feature the border barrier system from the 1950s in red lines, while the later stage of the barrier construction is marked in blue.

Broader settlement areas and their settlements are compared within the zones defined by the above borderlines, with the zone closer to the border being marked (as was common at the time) as prohibited, the zone between the red and blue lines as border zone and the rest as inland.

In all the three zones, the extinction followed a process. In the prohibited zone, this process was shorter than in the inland, there are some exceptions, though. We can also state, albeit with a few exceptions, that in the researched period between 1945 and approximately 2011, the extinction process in the inland areas took longer than in the prohibited and border zones, where, on the other hand, an influence of the postdepositional transformations on the extinct components was long-term.

The map in Figure 29 captures the entire surveyed area delimited by the state border in the south (bold red broken line) and the artificial border of the surveyed area in the north (thin red broken line). All the settlements are marked by an abbreviation of the name or the symbol for the broader settlement area. The map in Figure 29, capturing the settlement situation in ca. 1945, indicates a low density of settlements in the border zone, which is however, due to the high forestation rate. The increasing number of settlements on the very border with Austria, in the later prohibited zone, is due to the proximity of this border area to the farmlands on the Austrian side of the Novohradské Mountains.

Figure 30 shows the settlement divided by the first generation engineered technical barriers (thin solid red line) in about 1952. The subsequent situation, in about 1958, is presented in Figure 31: in the prohibited zone between the state border and the first generation engineered technical barriers (thin solid red line); there are no settlements and a decline in the density of settlements zones in the inland areas. The situation depicted in Figure 31 demonstrates that the settlements became extinct essentially to the same extent in the border zone and inland. In Figure 32, the settlement of the Novohradské Mountains and foothills during the shift of the boundaries of the 
forbidden zone and the engineered technical barriers further inland (thin solid blue line) is depicted. As can be clearly observed, the forbidden zone has been shifted to the already depopulated area.

The research indicated that the removal of the German nationals was not the determining factor leading to the ultimate abandonment of the settlements and the change in the nature of the landscape, but merely one of several factors. Many villages and settlements, particularly in the border and the prohibited zones, were resettled, and although the new settlers migrated, it can be assumed that in some places, especially in the border zone with relatively favourable conditions for permanent inhabitation, migration would eventually stop and the situation would stabilize, as was indeed the case of many places inland. Before this stabilization could occur, between 1951-1952 the prohibited zone on the Czechoslovak side was fortified by a high-voltage electric fence. People who lived in the villages situated within the prohibited zone were forcibly displaced.

A political selection was applied in the border zone, the people's movement was limited and the number of jobs decreased. This change in the way of life in the border zone, along with the harder living conditions in the isolated settlements located in the woods, resulted in the further population outflow, which was also amplified by the persisting sufficiency of available real estate deeper in the inland areas. In the last stage, in the second half of the 1960s, only that part of the population of the villages in the border zone remained whose sustenance was, to a significant extent, dependent on the garrison. Whenever a garrison closed, the civilian population soon followed (Pohoří - Puchers is a typical example). The depopulation was thus not necessarily a result of the construction of the border barrier system which took place in the second half of the 1960s and the first half of the 1970s. The line of the barrier system stretched along the border of the settled area, which is demonstrated by a significant proximity to the border in the permanently settled areas, such as Dolní Dvořiště - Unter Heid, where however, a border crossing was situated and, primarily, the area of Šejby - Scheiben in the east of the surveyed area. In these cases, practical economic reasons outweighed state security aspects.

A different development occurred in the inland zone of the surveyed area. Although the number of new settlers was significantly lower than the number of original population, the archaeological research demonstrates that the population of most farming settlements was replenished. The research proves that in the villages with compact centres, such as Hodonice - Hodenitz, as well as in the settlements with scattered farming development, such as Svatý Vít - Sankt Veit, only some farmsteads were repopulated, which was due to the fact that the newcomers were allocated more land than the farmsteads originally possessed. Both in the scattered development and in the compact centres, the primarily large farmsteads situated in easily accessible areas were resettled, while the individual houses were left to decay naturally (e.g. Hodonice - Hodenitz). After 1948, however, the newcomers were gradually loosing land due to the confiscation plan and the fact that agriculture was collectivized. The ability to make a decent living without one's own farmland and without dependence on dubious work of other co-op members decreased. The best farmers, for whom farmland was 
the main reason to move to the area, left when they were deprived of it. This gradual socialization caused a decline in trades and local services. The departure of the main farmers caused another wave of internal migration. Those who stayed would leave their farmsteads and move to the better preserved buildings vacated by the departing landowners. These vacated farmsteads often became, temporarily or even permanently, business premises of the Unified Cooperative Farms, which were later transformed into the State Farms. The abandoned houses and farmsteads were taken apart by the neighbours and the people from the nearby villages and settlements. During that time of constant shortage, anything that could be transported would come in handy: equipment, construction material, firewood and others. As the collectivized agricultural production became prominent, the remaining population reduced the original scope of the remaining farmsteads to the living part (former farmsteads became houses) or, which prevailed, they moved to the areas of centralized agricultural production. It seems that the closer a vanishing village was to another one with agricultural operation, the faster it disappeared (e.g. Velíško - Wölschko). On the other hand, in the places which were distant from the centres of agricultural production, the detached units were preserved and so the population stayed there as well (e.g. Hodonice - Hodenitz, Obec - Obst, Drochov - Drochersdor). However, when the capacity for cattle stabling or fodder storage was sufficient, the detached units were no longer necessary. In addition, the growing capacity of farming machinery allowed for the cultivation of distant farming land without the necessity to have farm workers living there permanently. The entire infrastructure was concentrated in the centres of agricultural production, while remote villages lacked schools, shops, services and jobs. Public transport was unavailable there and the local roads were in poor condition. The departure of the last inhabitants was followed by the dismantling of houses, and eventually by demolitions. Subject to demolition were mainly those farmsteads and entire villages that were close to other populated settlements or those that were visible from the main or side roads. The remote villages and settlements were left to natural decay and gradually became overgrown with trees and other vegetation.

All this led to a long-term phenomenon of depopulation that has still not been reversed. During the period of the centrally directed economy, the non-use of the potential of the territory whose economic benefits were still well remembered, signified a considerable political problem that had to be ideologically justified and practically disguised. The establishment of the forbidden and border zone would have been useful in concealing that major political failure. The impoverished borderlands had to be hidden from enemies from abroad and within as both of them could use it in their "hostile" propaganda. The destruction and demolition of structures after 1951 was the most common way to render extinction of the human dwellings affected by depopulation. The structures to be first demolished were either those that were visible from the settlements in the Austrian border areas, or visible from a functional village on the Czech side of the borders. After that, the demolition was applied to the structures which were visible from some roadway and used by the Czech civilian population and finally to the unoccupied and dilapidated buildings in the partially inhabited Czech villages. On the other hand, the structures that were inaccessible and not visible to a domestic or foreign civilian 
observer were left to gradually dilapidate. Obviously, there are some exceptions, or the cases where the degree of visibility is difficult to judge today. But the unspoken objective of the communist propaganda - to manipulate the historical consciousness and let the memory of once flourishing border areas disappear into oblivion - succeeded almost without exception. 